\title{
A kulturális evolúció újabb elméletei a hagyományok tükrében
}

A tanulmány a kulturális evolúció két, többek által riválisnak tekintett elméletének, nevezetesen Dawkins mém- teóriájának, valamint Dan Sperber ún. epidemiológiai elméletének alkalmazhatóságát és korlátainak lehetőségeit vizsgálja. Ahelyett azonban, hogy egy újabb teoretikus konstrukciót hozna létre, inkább a modellek konkrét alkalmazhatóságát állítja előtérbe. Ehhez a néprajz és a kulturális antropológia eddigi eredményeit, s ennek kapcsán bizonyos módszertani elemeit hívja segítségül, elsősorban is Robert Redfield "kis tradíció - nagy tradíció” elméletét.

\section{Szerzői információ:}

\section{Mund Katalin}

1971-ben született Budapesten. A buddhista teológia elvégzése után az ELTE Szociológiai Intézet harmadéves hallgatója. Eddig fơképpen vallásszociológiai témákban jelentek meg tanulmányai. Fontosabb publikációk: Divináció és szociológia (Iskolakultúra 6-7. 2001.), Kelet Istenei Nyugaton (Ethnographia 2001.), Rekviem egy elveszett mítoszért (Valóság 2001/8.), Szúkülő világegyetem (Liget 2002/6.), Az egészség és tisztaság kultusza mint új vallási cél (Liget 2002/7.) Jelenleg a magyarországi politikai pártok szocializációs mechanizmusait, illetve a választási kampányokat vizsgáló kutatásban vesz részt az ELTE keretein belül. Farkas Attila Mártonnal egy, a magyarországi nem keresztény, új vallási mozgalmakat tárgyaló könyvön dolgozik.

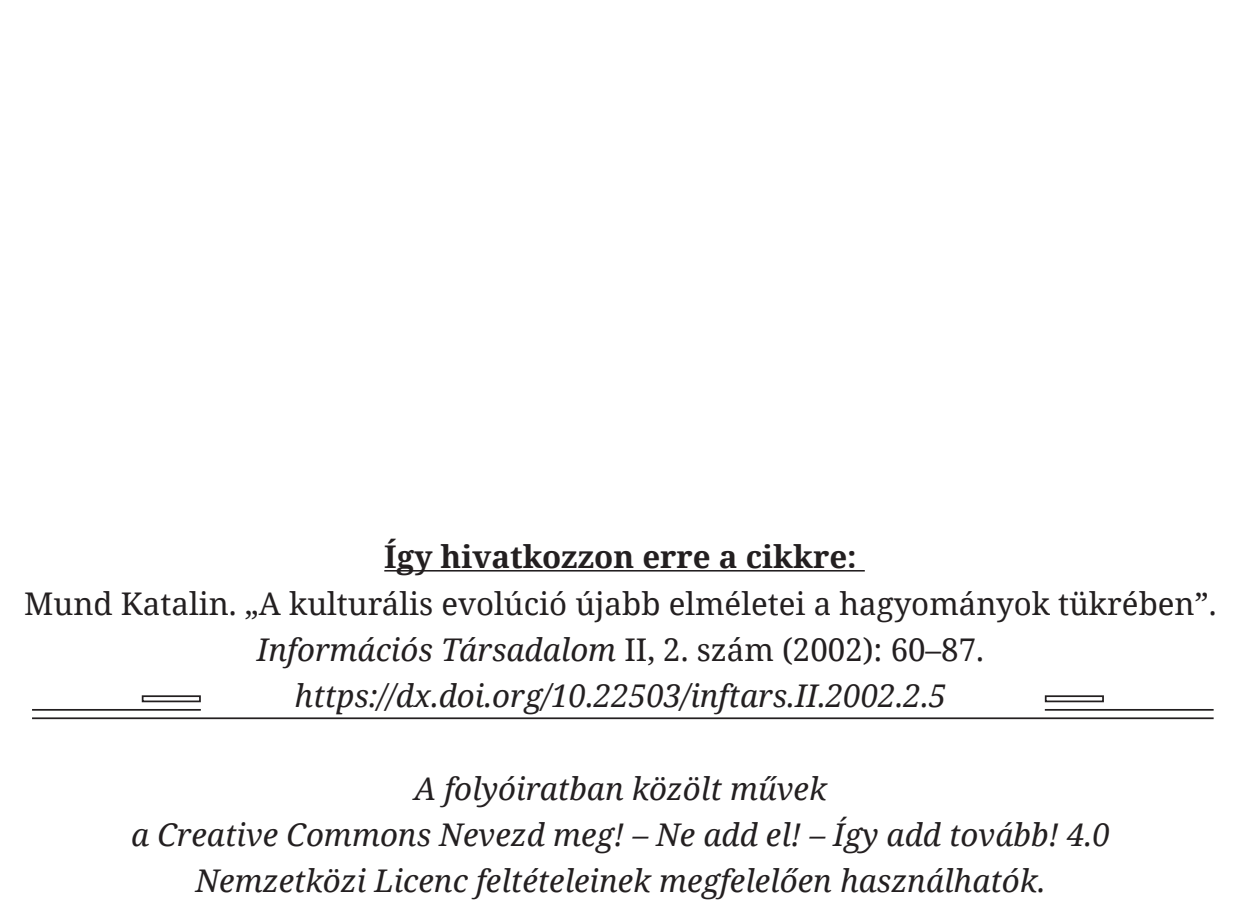




\section{A kulturális evolúció újabb elméletei a hagyományok tükrében}

Sevillai Szent Izidornak, as Internet védöszentjének

Pléh Csaba „A gondolatok terjedési mechanizmusai: mémek vagy fertôzések” címú tanulmányában a biológiai evolúciós szemlélet segítségével Dawkins és Sperber munkáira támaszkodva a reprezentációk terjedési mechanizmusait vizsgálta (Replika 40. szám). A két elméletet (Dawkins memetikai és Sperber epidemiológiai teóriáját) mint kétféle, lényegében egymást kizáró elképzelést mutatta be. A jelen tanulmány célkitűzése hármas: egyrészt a makrofolyamatok szintjén vizsgálódva azt kívánom bemutatni, hogy ez a két megközelítési mód nem kizárja, sokkal inkább kiegészíti egymást. Segítségükkel a kultúra bizonyos jelenségeiról teljesebb, pontosabb képet alkothatunk. Ugyanakkor arra is választ keresek, hogy a kétféle analógia - egy mélyebb analízis során - mennyiben használható a kulturális változásokra, azaz a mikrofolyamatok szintjén hol húzódnak az analógiák esetleges korlátai.

Tanulmányában arra is felhívja figyelmünket Pléh Csaba, hogy az említett terjedéselméletek mindezidáig csupán teoretikus modellek. Ahhoz, hogy ha nem is magyarázó, de legalább taxonomikus modellé váljanak, „arra lenne szükség, hogy legalább esettanulmányok szintjén valóban alkalmazzák az elméletet”. A jelen írás harmadik célkitűzése tehát nem más, mint hogy kijelöljön egy ösvényt, amelyen elindulva talán megszülethetnének valódi esettanulmányok. A kulturális antropológia egyik ismert elméletén keresztül a memetikai/járványtani metafora egy sajátos alkalmazási módját is megkísérelem felvillantani.

Az említett antropológiai elmélet Robert Redfield nevéhez fúződik, aki fooként a paraszti társadalma(ka)t vizsgálta (Redfield, 1956). Kimutatta, hogy a paraszti közösségek kultúrája nem autonóm, hanem egy nagyobb egész (egy civilizáció) szerves része. Ahhoz, hogy a paraszti kultúra fenntarthassa magát, folyamatos kommunikációra van szüksége egy rajta kívül álló gondolatrendszerrel. Éppen ezért egy paraszti közösség kultúrája nem érthetô meg önmagában, a megértéshez feltétlenül szükséges azon papok, tanítók, filozófusok - azaz a centrum képviselői - gondolkodásmódjával is tisztában lenni, akik ugyan többnyire soha nem jártak az adott faluban, ám akiknek gondolatai befolyással bírnak, hatással vannak a paraszti kultúrára. Ugyanis a paraszti társadalmat főként az különbözteti meg egy hagyományos primitív társadalomtól, hogy míg az utóbbi egy komplett kulturális univerzum, egy önmagában megálló egységes egész, addig az elóbbi amolyan „féltársadalom” (half-society), amely évszázadokon keresztül folyamatos kapcsolatban állt a civilizáció központjaival, a mindenkori uralkodó kultúrával. Redfield ennek értelmében - elsôsorban a vallásokra fókuszálva - a nagy civilizációkban egy kettôs kulturális struktúrát vázol fel, ún. „nagy tradíció”ról és „kis tradíció”-ról beszél. Az előbbi nagyjából a „magas kultúrának”, a „klasszi- 
kus” vagy „elit” kultúrának, illetve a tanultnak a szinonimája. Ezzel szemben az utóbbi az „alacsony” vagy „népi” kultúráé, a populárisé (Redfield, 1956:70). Minthogy írásom kiindulópontja Redfield elmélete, ezért megmaradok az általa választott fogalompárnál, azaz a továbbiakban kis és nagy tradícióról beszélek, ám Redfieldhez hasonlóan azt a viszonyrendszert értem ezalatt, amit ezek a fogalompárok (is) jelölnek.

Egy civilizációban a nagy tradíció a gondolkodó kevesek sajátja, míg a kis tradíció többnyire a „nem elmélkedô többséghez” köthetô. A nagy tradíciót iskolákban és templomokban ápolják, míg a kis tradíció lényegében önmagát tartja múködésben a múveletlenebb falusiak életmódján keresztül. A nagy tradíció a városokban van jelen, jellemzố rá a tudatos átadás, a mesterséges fenntartottság, míg a kis tradíció a vidékhez, a faluhoz köthetố, a népi kultúra része, mely fóleg a formákban, ôsi kultuszokban gyökerezik, s amelynek áthagyományozódása öntudatlan. ${ }^{1}$ A nagy tradícióban a domináns elem a magyarázó elképzelés. A kis tradícióban ezzel szemben a tudattalanul átöröklött kulturális formák dominálnak. A kis tradíciót az emberek nem kérdôjelezik meg, nem gondolkodnak el róla, hanem egyszerúen elhiszik. A nagy tradíció mindenkor újítás révén jön létre, a kis tradíció viszont az időtlen hagyományok ôrzője, a konzervativizmus melegágya. A kétféle tradíció fổ jellemzói Redfield elméletében tehát a következők:

\begin{tabular}{l|l|} 
Nagy tradíció: & Kis tradíció: \\
\hline globális, univerzális & lokális \\
\hline urbánus & rurális \\
\hline elit gondolkodás & népi vallásosság \\
\hline újítás eredménye & hagyományok őrzôje \\
\hline tudatos átadás, & tudattalan \\
mesterséges & áthagyományozódás \\
fenntartottság &
\end{tabular}

A kis és nagy tradíció folyamatos kölcsönhatásban állnak egymással. Az Ótestamentum etikája például egyfajta törzsi etikából emelkedett ki, majd visszatért a falusi közösségekhez miután teológusok és filozófusok gondolkodásának tárgya volt (Redfield, 1956:71). Ugyanakkor - és ez témánk szempontjából nagyon fontos jellemző - a tanításokat a parasztság (ill. a kis tradíció képviselői) csaknem mindig másképpen értelmezi, mint azt a tanítók, papok avagy filozófusok eredetileg átadni szándékozták.

A kétféle tradíció izolált törzseknél, vagy hordáknál nem mutatható ki. Ezekben a közösségekben például egyáltalán nem találjuk meg a vallások semmiféle aspektusát. „Szemmel láthatóan akármelyik idősebb személy ugyanolyan valószínúséggel tudja, amit tudni kell, mint bárki más" (Redfield, 1956:72). Hogy a nagy, illetve kis tradíció mely törzseknél, kultúráknál mutatható ki, nos ez nem függ sem a törzs méretétốl, sem pedig fejlettségi fokától. Így például a nigériai Tiv törzsnél, amely kb. egymillió földmúvest számlál, „,nincsenek szakképzettebb osztályok, vagy bárminemú kisebb specializálódás, azon túlmenôen, amit a nem illetve az életkor eredményez. A törzsi élet minden aspektusa mindenkire tartozik" (East, 1930:11). Más társadalmakban viszont a tudás idővel megduplázódik, más lesz a nép tudásának tartalma és más az elit csoportté. Egy Kína vallásosságát vizsgáló antropológus, Wing-tsit Chan írta például a következóket: „Ahelyett, hogy a kínai emberek vallásos életét három cso- 
portba sorolnánk, név szerint a konfucianizmus, a buddhizmus, valamint a taoizmus alá, sokkal pontosabb, ha két szintet állapítunk meg: a tömegek szintjét és a megvilágosodottakét” (Redfield, 1956:81). Egy másik szerzô, Derk Bodde filozofikus és népi taoizmust különböztet meg: „A filozofikus taoizmusban az ember természettôl való függésén van a hangsúly, míg a vallásos taoizmusban mágikus módszerek segítségével az emberi halhatatlanság megszerzése a cél; hasonlóképpen a filozofikus taoizmusban az isteni okság ideája szigorúan ki van zárva, míg a vallásos taoizmusban az univerzumot antropomorf istenségek hatalmas seregei népesítik be.”2

Arra, hogy a nagy tradíció tanításai, miként értelmezôdnek, színezôdnek át a kis tradícióban, Redfield a következő érdekes példát hozza: A Vénusz bolygóhoz kapcsolódik a Kilenc Éjszaka Fesztiválja, melynek során kilenc napon keresztül ünneplik a „nagy tradíció” panteonjának istennôit Indiában. Egy Kisham Garhi nevú faluban azonban az emberek egy Naurtha nevú lényt is megünnepelnek. Minden reggel és este kilenc napon át nők és gyermekek énekkel és agyagfigurákkal köszöntik Naurthát. Naurtha azonban nem található meg a nagy tradíció panteonjában. A „nava ratra” kifejezés, melynek jelentése: „kilenc éjszaka” egyszerú félreértése teremtette meg eme istennőt a kis tradíció számára (Redfield, 1956:96-97).

Kis és nagy tradícióról csak együttesen beszélhetünk, hiszen ugyanannak a kulturális rendszernek alkotják egy-egy aspektusát. Voltaképpen tehát itt egy viszonyrendszerrốl van szó, amelyben a kis tradíció nem egy autonóm lokális kultúra, hanem egy lokális kultúrának a nagy tradíción belüli, azáltal meghatározott, tudattalan továbbélése, voltaképpen túlélése.

Redfield megkülönböztet „elsôdleges” és „másodlagos civilizáció”-kat. India vagy Kína civilizációját elsődlegesnek tartja, mert - érvei szerint - azok saját civilizáció előtti népeik kultúrájából fejlődtek ki. Másodlagos civilizációról pedig akkor beszélhetünk, ha egy létezố kultúrát egy másik, terjeszkedố kultúra elnyom. Ez utóbbira Amerika meghódítását hozza fel példának. Ebben az esetben egy jóval összetettebb kulturális struktúrát kapunk, hiszen több nagy tradíció fog keveredni több kis tradícióval. Mindazonáltal, mivel India vagy Kína kultúrájára ugyancsak számos hódító civilizáció hatott, úgy vélem, pontosabb képet kapunk, ha három típust különböztetünk meg:

1. Autonóm kultúrák, amelyek szerves egységet alkotnak, mint amilyen a már említett nigériai Tiv törzs. Egy ilyen típusú, viszonylag egységes kultúrában rendszerint egy misszionárius, azaz egy idegen hódító eszme megjelenése indíthatja be a kultúra megduplázódását, azaz a kétféle tradíció kialakulását.

2. Egyes kultúrák fejlődésük során úgy változnak meg, hogy minden jelentősebb külső hatástól függetlenül duplázódnak meg. Ilyen volt a maja vagy az egyiptomi civilizáció. Ezekben a kultúrákban önmagától kialakult a nagy tradíció/kis tradíció kettôssége.

3. Egy-egy ilyen fejlettebb civilizációt is elérhet azonban valamely hódító eszme, ilyenkor a nagy tradíció megváltozhat, ám a kis tradíció tudattalan formái továbbra is fennmaradnak.

A kis és nagy tradíció tehát lényegében egy adott kultúra tudásának megkettốződésével létrejött, viszonylag statikus állapot, amely kétféle tudás jellegzetességei- 
nek eltérése. Ez legérzékletesebben éppen azokban a kultúrákban mutatható ki, amelyeket egy idegen kulturális behatás (mondhatni: elnyomás) ért. Ilyenkor tûnik ki ugyanis, hogy bár a nagy tradíció folyamatosan megváltozhat, a népi kultúra lényegét tekintve változatlan marad. Ez a változatlanság a hagyományokban érhetô tetten, pontosabban az áthagyományozott formák és azokhoz kapcsolódó funkciók állandóságában. Az „állandóság” fogalmával persze csínján kell bánnunk. Az etnográfiában hosszú ideig tartotta magát a népi világ ahistorikusságának tézise, amelyet Josef Dünninger fogalmazott meg legvilágosabban: „A népiesség örökké állandó, idôtlen, az évszakok természetes váltakozásában valóra váló, a legbelsőkig változatlan, az őskezdet által formált és eleve meghatározott idő nélküli, de térbeli” (Dünninger, 1937:21; Bausinger, 1995:20). Az utóbbi idốk kutatási eredményei azonban azt mutatják, hogy értelmetlen a népi kultúrát a paraszti életmód érintetlen formájaként kezelni, sokkal helyesebb történetileg változó mivoltában megragadni. Amikor tehát a továbbiakban bizonyos kulturális jelenségek állandóságáról beszélek, akkor azt lényegében Hermann Bausinger megállapításának értelmében teszem, miszerint „amennyiben népi világon nem egy képzeletbeli időtlen eszmeiséget értünk, hanem az „egyszerú nép" valódi szellemi és materiális világát, akkor ez a világ a történetiség területéhez tartozik. Csupán annyit jegyezhetünk meg, hogy a népi világ jellemző javai - a magas kultúra javaival összehasonlítva - relatíve nagyobb állandósággal rendelkeznek; ám egyes esetekben még ezt is felül kell vizsgálni” (Bausinger, 1995:20). Nézzünk két példát, mirôl is van szó:

Elsőként is - még Keleten maradva - ragyogóan illusztrálja az elméletet a buddhizmus tibeti elterjedése. Bizonyos jelek arra utalnak, hogy a buddhizmus már a VII. század elốtt elkezdett beszivárogni Tibetbe. Az elsố tibeti kolostort a VIII. században Triszong Decen király alapította, aki három nagy indiai szerzetest (mestert) hívott udvarába: Sántaraksitát, Kamalasílát és Padmaszambhavát. A legsikeresebb tanítónak ez utóbbi bizonyult, a mítoszok tanúsága szerint ugyanis ô volt képes leigázni a helyi isteneket. A buddhizmus tehát korántsem szűz területre érkezett, hiszen egy erôsen sámánisztikus hagyomány, a bon vallás fogadta. ${ }^{3}$ A kettő keveredését Eliade többek között a következô példával szemlélteti: „A bon sámánok arról nevezetesek, hogy dobjukat közlekedési eszközként használják, a levegóben tudnak vele helyet változtatni. Ennek egy klasszikus példája Naro bon c'hun repülése Milarepával folytatott mágikus vetélkedése alkalmával. «Az a legenda, mely szerint Shen rab mi bo egy nagy keréken utazott, amelynek ő a közepét foglalta el, míg nyolc tanítványa egy-egy küllőn ült, valószínúleg hasonló hagyomány továbbélését mutatja. « A jármủ kezdetben alighanem a sámándob volt, melyet csak később helyettesítettek a buddhista szimbólummal, a kerékkel” (Eliade, 2001:391-392). Nézzünk egy másik érzékletes példát: a csöd nevú rítus során, az ember felajánlja testét a démonoknak, hogy azok cafatokra tépjék és felfalják. Ez a hagyomány különös módon emlékeztet arra, amikor a leendő sámánt az ôsök szellemei feldarabolják. Az ôsi rítus során elhangzó szavak azonban már a buddhista mítoszt mesélik el: arról szólnak, hogyan adta a Buddha a saját húsát a kiéhezett állatoknak valamelyik előző megtestesülése alkalmával. Jól látható, hogy míg az eredeti rítus fennmaradt, a jelentése megváltozott, hiszen a buddhizmus ezen példázata a szeretetet, az együttérzést hivatott felkelteni a törekvő́ben. A buddhizmus tehát mint tipikus hódító eszme, találkozott a bon helyi hagyományával, s az eredmény a kettôs tradíció kialakulását eredményezte. Azonban míg a buddhizmus 
elveszítette eredeti formáját, a bon éppen a formát ôrizte meg, megtöltve azt az előbbi által képviselt új tartalommal. Eliade a változást a következőképpen foglalta össze: „A tibeti anyag e rövid áttekintése lehetôvé teszi (...), hogy kimondjuk: a buddhizmusban és a lámaizmusban sámáni témák és technikák maradtak fenn. A »fennmaradás « talán nem fejezi ki elég világosan a dolgok valódi állását; inkább az ősi sámáni motívumok átértékelődéséről kellene beszélni, és beilleszkedésükrôl egy aszketikus teológiai rendszerbe, ahol még tartalmuk is gyökeres változáson ment át. Mi sem természetesebb egyébként, ha arra gondolunk, hogy a buddhista kritika következtében magának a sámánideológiában alapvető »lélek «-fogalomnak is teljesen megváltozott az értelme. Bármilyen visszafejlődési fokot jelentsen is a lámaizmus a nagy buddhista metafizikai hagyományhoz képest, a »lélek « realista felfogásához nem térhettek vissza, s ez az egyetlen pont is elegendő volt ahhoz, hogy a lámaista technika tartalmait megkülönböztessük a sámáni technika tartalmaitól” (Eliade, 2001:398). Ámde nem a formájától!

De nem kell olyan messzire mennünk a példákért, hiszen a jelenség a mi kultúránkban is kimutatható. Vallástörténeti közhely, miként éltek tovább bizonyos pogány ünnepek, ôsi kultuszok, vagy éppen antik istenek a katolicizmuson belül. Érzékletesen szemlélteti a jelenséget Szent Kristóf figurája, akit kutyafejjel, ám embertesttel ábrázolnak. Szent Kristóf nem csupán külsejével emlékeztet az egyiptomi Anubiszra, a sakálfejû́ istenre, akit a Római Birodalom idején már inkább kutyafejjel ábrázoltak, de a sakálisten bizonyos funkcióit is átvette. Igy nem csodálkozhatunk azon, hogy Szent Kristóf éppen az utasok, a tengerészek, illetve az orvoslás védőszentje. Az egyiptomi Anubisz, illetve azzal rokon sakálistenek voltak az Alvilág útjának megnyitói, azok az alakok, akik felbukkannak a nap-bárka utasai között is, továbbá lélekvezetők, mint Hermész a görögöknél. Anubisz a túlvilági utazást felügyelte, valamint ő volt a balzsamozás istene, a halottak táplálója, aki voltaképpen visszaadta a halottnak életfunkcióit. Vagyis Szent Kristóf figurájában a formával együtt az eredeti funkció is tovább élt (Dobrovits, 1979:217-232). Hozzánk sokkal közelebbi példában is hasonlóképpen élt tovább a magyar Mária-kultuszban a korábbi istennô, a Nagy Boldogaszszony kultusza. De nem szükséges annyira visszatekintenünk hasonló példákért az európai történelemben sem: a forradalmi Franciaországban például, azután, hogy betiltották a Jézus-szíve körmeneteket a nép Marat-szíve körmeneteket tartott.

Az említett esetekbôl is kitűnik, hogy emberek a megszokottat kedvelik (kognitív beágyazottság), ezért, amikor egy új tartalom akar megjelenni, az egy már megszokott formát választ magának. Így például Szent Kristóf, mint keresztény szent (tartalom!) kutyafejü (forma!) istenségként jelenik meg. De miért éppen a kutyafejű istenség, az egykori Anubisz, lesz Szent Kristóf? Miért nem valamely más isten? A kettốben kell, hogy valami közös legyen. Ez a közös elem nem más, mint a funkció. Jelen esetben: az utazás, az utak védelme, a hajózás, illetve a balzsamozás/gyógyítás. A helyzetet bonyolítja, hogy a jelenség magyarázatára két szempontot is felvehetünk. Anubisz szempontjából elemezve a változást azt mondhatjuk, hogy a régi isten tudattalanul (kis tradíció) tovább él, egykori jelentéstartalmától megfosztva, survivalként. Ha azonban Szent Kristóf szempontjából vizsgálódunk, akkor azt állapíthatjuk meg, hogy a kereszténység (a hódító új eszme) csak úgy lehet sikeres, hogy hordozóként használja a régi formákat. Az eszméknek úgy túnik nincs rögzült formájuk, már kialakulásuk pillanatában egy meglévő forma-készletre támaszkodnak. Ugyanakkor ezzel 
párhuzamosan megfigyelhető, hogy fokozatosan kiüresednek, formálissá válnak (pl. egy vallás intézményesül), és eltûnik belôlük az útkeresés, a szellemi frissesség. ${ }^{4}$ Ez pedig mindig akkor történik, amikor kialakul a kis tradíció-nagy tradíció kettôsség, amikor tehát az adott lokális kultúra rögzült formái elnyelik a behatoló új eszmét (azaz szemantikai tartalmat). Más szóval a hódító eszme behatol a lokális kultúrába, kisajátítja a formákat, ezáltal viszont maga is formalizálódik, azaz tartalmat vesztett formává lesz. Pontosabban: a névleges tartalom ugyan megmarad, de elveszik a „valódi” tartalom. Egy forma természetesen soha nem „üres”. Nem üres, hiszen például egy rítus, egy szokás bizonyos kultúrfunkciókat azután is betölt, hogy a résztvevôk, a hívôk esetleg már nem tudják, mi volt az eljárás eredeti (azaz valós) értelme. Ha az eredeti információ-tartalom már el is veszett, a közösséget összekovácsoló funkció, az együtt ünneplés által keltett öröm érzete, stb. továbbra is megmaradhat. A „kiüresedés" fogalma alatt - jobb szót nem találván a jelenségre - az eredeti tartalom elvesztését értem, azt, amikor az eredeti tartalom már-már a felismerhetetlenségig eltorzul, illetve helyébe annak valamiféle csökevényes változata lép, esetleg teljesen eltûnik és egy másik tartalomnak adja át a helyét. Merthogy például egy rítusba az azt végzók mindenkor belelátnak, belemagyaráznak valamit, vagyis új információval töltik fel a megmaradt formát, ám történelmi tudásunk alapján tudjuk, hogy az eredetileg egészen mást jelentett, hogy az eredeti tartalomnak legfeljebb halovány nyomai őrződtek meg. ${ }^{5}$ Szépen példázza ezt a folyamatot Szent Katalin képi ábrázolásában - és ezzel párhuzamosan legendájában - bekövetkezett változás. A történet szerint Szent Katalint Maximinus császár késekkel kirakott kerékbe akarta töretni, ám a szent csodatevő ereje a kereket darabokra törte. (Később azért lefejezték.) Szent Katalint kezdetben a legendára emlékezvén egy kerékkel ábrázolták. Az idók során azonban a képen a kerék mérete mind kisebbé változott, míg végül a szent a két ujjával fogja, az addigra gyưrûnyi méretűvé változott kereket. Ahogyan csökkent a kerék mérete, úgy merült feledésbe az eredeti legenda. Idővel már senki nem tudta, mit jelent az a picike kerék Katalin kezében. S ekkor új legenda született, miszerint Szent Katalin misztikus eljegyzést kötött Krisztussal, a képen látható pici kerék pedig nem más, mint eljegyzési gyưrú. Látjuk tehát, hogy az ábrázolás eredeti információ-tartalma eltűnt, ott maradt egy tartalom nélküli forma (ti. a kerék), amelyet azután új tartalommal (jelentéssel) töltöttek föl.

A kis tradíció és a nagy tradíció ennek megfelelően egy-egy tudás-típussal is öszszefüggésbe hozható. Az előbbi a „tudni hogyan”, míg az utóbbi a „tudni mit” értelmében nevezhetô tudásnak. ${ }^{6}$ (Mindazonáltal a kis tradícióban is megjelenhetnek „kvázi ontológiák” az egyén szintjén, most azonban a kultúra szintjén vizsgálódunk.) Mindezt az alábbi táblázatban foglalhatjuk össze:

\begin{tabular}{l|l|} 
Nagy tradíció: & Kis tradíció: \\
\hline tartalom & forma és funkció \\
\hline explicit tudás & implicit tudás \\
\hline keresztény szent & kutyafejű emberalak \\
\hline buddhista szerzetes & kvázi sámán \\
\hline explicite buddhizmus & implicite bon
\end{tabular}


Összegzésképpen elmondhatjuk, hogy a kultúrákban vannak tudattalanul átöröklődő formák, amelyek képezik a kis tradíció lényegét. Ám vannak másféle reprezentációk is, amelyek átadódása, terjedése, tudatos folyamatok eredménye. Ezek azok a hódító eszmék, ideológiák, vallások, stb., amelyekből idôvel nagy tradíció válhat. Eme kétféle terjedési mechanizmus két eltérô analógia felállítását teszi indokolttá, ám látni fogjuk, hogy a két elmélet egyetlen szerves egészet képezhet.

Mielốtt azonban a különféle biológiai analógiák vizsgálatára rátérnénk, fontos hangsúlyozni, hogy a redfieldi elmélet, csakúgy mint a következókben leírt analógiák csupán modellek. A modellek pedig voltaképpen a természet karikatúrái, hiszen néhány lényeges jellemvonást felerôsítenek, a többit viszont elmossák. Így tehát csupán segítenek megérteni bizonyos jellemzóket, ámde nem kecsegtetnek a valóság hû́ leírásával. Szó nincs tehát arról, hogy egy kultúra annyira egyszerủ lenne, mint amilyennek a modellek mutatják! Egy kultúrát csak egy végtelenül összetett struktúrával írhatnánk le, hiszen nyilvánvaló, hogy számtalan egymást átható réteg létezik, nem csupán kettô. Jelen dolgozat azonban a hagyományokat átörökítố kognitív struktúrák rétegzettségét, illetve a hagyományok belsố szerkezetét vizsgálja, amelyet elsố lépésben csak az ilyen elnagyolt, leegyszerúsített modellek segítségével közelíthetünk meg. Mindazonáltal ez csupán egy segédeszköz, (Wittgenstein képével élve) létra, amelyet, ha felmásztunk rajta, el kell hajítanunk (Wittgenstein, 1989:90).

\section{Mém kontra vírus}

A Richard Dawkins nevéhez köthető mém-elmélet a gének analógiájára a kultúrában is feltételez replikálódó egységeket. „A mém lehet egy dallam, egy gondolat, egy jelszó, ruhadivat, edények készítésének vagy boltívek építésének módja” (Dawkins, 1986:241) Azaz „a komplex ideák azon fajtája, melyek önmagukat kïlön megjegyezhetô egységekké képesek alakítani” (Dennett, 1998:370). Dawkins szerint a mémek „agyból agyba költöznek egy olyan folyamat révén, amit tág értelemben utánzásnak nevezhetünk" (Dawkins, 1986:241). A mémek „öntudatlan, vak” replikátorok, amelyek az evolúció személytelen algoritmusának (variáció, szelekció és öröklődés) „engedelmeskedve” terjednek el egy adott kultúrában. A terjedés tehát automatikus, tudattalan és kontrollálatlan. Ha most visszatekintünk a fent tárgyalt kulturális jelenségekre, akkor úgy túnik a mémkoncepció ismertetôjegyei a kis tradícióval mutatnak rokonságot. Hiszen mi is a kis tradíció? A kulturális formák tartalom nélküli, lokális, tudattalan öröklődése. (Voltaképpen a néprajzi survival jelensége.) Ez az öröklődés ráadásul a kultúrában vertikálisan terjedő, generációról generációra való áthagyományozódás. A formák, minták (szokások, rítusok, stb.) viszonylag pontosan másolódnak, noha óhatatlanul megjelenhetnek mutációk is. Mindent egybevetve úgy túnik, a gén-analógia meglehetôsen jól megragadja a jelenség lényegét. Dawkins azonban nem csupán a viszonylag pontosan másolódó, többnyire vertikálisan terjedő kulturális alapelemeket nevezte mémeknek, hanem a mém szót sokkal szélesebb értelemben használta. Nála, mint azt a fenti idézetbôl láttuk, a ruhadivat, a dallam vagy egy jelszó éppúgy mém, mint az edények vagy a boltívek elkészítésének módja, tehát a horizontálisan és vertikálisan terjedô elemek egyaránt.

Mindazonáltal fontos hangsúlyoznunk, hogy a mémek korántsem a gének szolgálói, hanem önálló, replikálódó egységek, amelyek olykor a gének ellenében is hat- 
hatnak (pl. az öngyilkosság mémje). „Egy kulturális jelenség lehet, hogy csak azért alakult úgy, ahogy alakult, mert ez önmagára nézve előnyös” (Dawkins, 1986:241). Ez különbözteti meg a mém-elméletet - hangsúlyozza Susan Blackmore - a hagyományosan kultúr-génekkel operáló elméletektől (Blackmore 2001:65-70). Ez utóbbiakban ugyanis a kulturális evolúció voltaképpen a biológiai evolúciót követi, (azaz „a gének tartják pórázon a kultúrát”). ${ }^{9}$ A paraszti kultúra (a kis tradíció) jelenségeinek vizsgálatánál, ha megmaradunk pusztán a kultúr-gén fogalmánál, azaz ha mindent biológiai, etológiai okokra vezetünk vissza, akkor olyannyira általános elméletet kapunk, amely lényegében szinte semmit nem magyaráz meg, legfőképpen nem a kultúrák sokféleségét. A mém, mint önálló, a génektôl viszonylag független második replikátor viszont alkalmas lehet a kultúra bizonyos típusú változásainak, sokféleségének finomabb, árnyaltabb leírására.

Ám mielőtt elhamarkodottan kiterjesztenénk az elméletet a kultúra egészére, meg kell vizsgálnunk a lehetséges ellenvetéseket is. A mémkoncepcióval szemben megfogalmazott egyik legfontosabb kritika a tudatosságra vonatkozik. „A gén-mém analógia tetszetôs” - jegyzi meg Pléh Csaba említett írásában -, „ha hirtelen kirobbanó divatok (mondjuk gyerekjáték- vagy felnôttjáték-divatok) jutnak eszünkbe. De vajon a terjedés ezen automatikus, kontrollálatlan, s fóként mérlegeletlen felfogása áttehetô-e minden tudásra, vagy a divattól eltérô rendszereknél nekünk, mint mérlegelő egyéneknek, s a mérlegelő közösségnek nagyobb kontrollunk van-e az átvétel felett?” Hasonlóképpen érvel Denett, amikor ironikusan és provokatívan megjegyzi: „A tudós pusztán egy módja annak, ahogy egy könyvtár másik könyvtárat hoz létre. Nem tudom, ki hogy van vele, de számomra nem igazán vonzó az a gondolat, hogy az agyam egyfajta trágyahalom, melyben más emberek gondolatcsírái új életre kapnak, mielôtt egy információs diaszpórában önmaguk másolatait elterjesztenék. Nagyon is úgy tûnik, hogy megfoszt engem elmém szerzői és kritikusi jelentőségétôl."10

Nos, úgy vélem a probléma megoldását nem feltétlenül a mémkoncepció elvetése jelenti. Ha így járnánk el, akkor a fürdővízzel együtt a gyermeket is kiöntenénk. Hiszen, amint láttuk a kultúrában igenis vannak tudattalanul terjedő reprezentációk, amelyek áthagyományozódásában elsôsorban lélektani és szociálpszichológiai tényezők (csoport hovatartozás, identitás erősítése, stb.) játszanak szerepet, s az átadás módja a „tág értelemben vett utánzás”. Például nem azért állítunk karácsonykor fenyőfát, mert tudjuk, hogy ez egy kb. kétszáz éves protestáns, német szokás, aminek valódi jelentése - hogy ti. a téli napforduló ünnepén a tavaszt, a termékenységet jelképezte, illetve a paradicsomi életfát - fontos volna számunkra, hanem azért, mert mások is így tesznek, mert ez a szokás, amiben nevelkedtünk.

Az izolált, autonóm törzsi kultúrák ritka kivételétốl eltekintve - ha a hagyományokat vizsgáljuk - megfigyelhetjük a struktúra kettôződését, azaz az elit eszme és a népi hagyomány közötti különbséget. Ez a kis falusi közösségekben éppúgy megjelenhet, mint a nagyobb civilizációkban. A magas kultúrát többnyire közvetítô személyek képviselik (sámán, törzsfőnök avagy a pap), akik a közösség tudásának szószólói, ápolói, velük szemben áll a nép tudása. Írásunk szempontjából most az az érdekes, hogy hogyan adódnak át a tudás-típusok, továbbá hogyan hat egymásra a kis és a nagy tradíció. Láttuk, hogy a kis tradíció jelenségeit egy öntudatlan áthagyományozódás tartja életben. De mi a helyzet a nagy tradícióval? Ez utóbbit templomokban, iskolákban ápolják, tudósok, filozófusok, papok elmélkednek róla. Az átvétel ebben az eset- 
ben korántsem automatikus folyamat eredménye, sokkal inkább az adott eszme tudatos újrakonstruálásáról beszélhetünk. A tudós, avagy a pap belátja az adott eszme igazságát, nem pedig egyszerűen elhiszi. Hasonló a helyzet az éppen hódító eszmék esetében is (függetlenül attól, hogy késốbb nagy tradíció válik-e belôlük). Az egyszerú parasztember, amikor Jehova tanúja lesz, akkor nem csupán átvesz egy kulturális rendszert, hanem megvilágosodik, a lét fundamentumának valamely mélyebb rétegét megérti. Jóllehet egy tudós ember megértése tartalmi szempontból többnyire mélyebb, alaposabb, mint egy egyszerú emberé, ám a kognitív folyamatok szintjén a megértés, belátás aktusa azonos. Röviden összefoglalva: az eszméket belátják, a szokásokat viszont megtartják! Az eszmék gyors terjedésénél tehát megértésrôl, belátásról beszélhetünk, amint azonban az adott eszme általánosabban elterjed egy kultúrában, az átadás elveszíti ezt a fajta tudatos jellegét. Akkor már csupán megtanulják. A „tanulás” kifejezés, ebben a kontextusban valódi megértés nélküli elsajátítást jelent. Lényegében tudatosság nélkül fogadják el a tartalmat, azaz elhiszik. Ekkor szoktuk úgy értékelni, hogy az adott eszme kiüresedett, közhellyé változott. Mindazonáltal könnyen megtéveszthet bennünket az, hogy ha megkérdezünk egy egyszerú embert, hogy mit miért tesz, az esetek többségében kapunk rá magyarázatot, azaz emberünk tisztában van például egy rítus jelentésével, kvázi-ontológiájával. Ilyenkor azonban csupán a megtanult értelmezést hallhatjuk vissza, ez azonban nem a: ó saját értelmezése lesz. A nem belátáson alapuló elsajátítás során az adott tartalom szinte változtatás nélkül kerül át, azaz voltaképpen replikáció történik. Amikor azonban a belátás szerepet kap a folyamatban, akkor egy tudatos re- vagy újrakonstruálásról beszélhetünk. Ebben az esetben az adott eszme könnyebben változhat, azaz mutálódhat. A kultúrában tehát kétféle öröklődés-típust látunk: a tudattalan folyamatokon alapuló replikáció mellett, vannak olyan reprezentáció-terjedések, amelyekben a tudatosság, illetve az átvevók pszichikai jellegzetességei játszanak kulcsszerepet. Dan Sperber járványtani modelljében ez utóbbira helyeződik a hangsúly (Sperber, 2001).

Sperbert a társadalmilag érvényes gondolati mintázatok érdeklik, pontosabban az, hogy az egyének fejében körvonalazódott gondolatok miképpen tudnak elterjedni a társadalom szélesebb rétegeiben, azaz hogyan válnak egyes gondolatok népszerúvé. Ennek érdekében egy epidemiológiai analógiát állít fel, amelyben különböző fertốzô betegségek terjedéséhez hasonlítja a gondolatok terjedését. A reprezentácók voltaképpen fertôzố ágensek, azzal a pontosítással, hogy míg egy baktérium, avagy vírus lényegében változatlan marad minden átadásnál, a reprezentációk átvitele aktív átalakításokat is jelent. A fogadó szervezet minden alkalommal saját rendszerének keretein belül konstruálja újra az adott eszmét, gondolatot. A hangsúly a kognitív mechanizmusokra esik, éppen úgy, mint amikor a nagy tradíció mesterséges fenntartottságáról, illetve egy hódító eszme terjedésérôl beszélünk. Bár Sperbernél teljesedik ki a gondolat, mindazonáltal már Dawkins elmélete is tartalmazta csírájában ezt a nézetet: „amikor azt mondjuk, hogy manapság minden biológus hisz Darwin elméletében, ezen nem azt értjük, hogy minden biológus agyába bevésôdött Charles Darwin pontos szavainak azonos másolata. Minden egyén a maga módján értelmezi Darwin gondolatait.(...) Darwin, ha olvasná ezt a könyvet, aligha ismerné fel benne saját eredeti elméletét" (Dawkins, 1986:245).

Dawkins és Sperber is úgy gondolta, hogy saját elméletével lényegében az összes kulturális elem terjedése leírható. Magam úgy vélem azonban, hogy célszerú a két elmé- 
letet egymástól megkülönböztetve együtt hasænálni aszerint, hogy mire helyezôdik az alapvető hangsúly. Dawkins elméletében az átvétel a „tág értelemben vett utánzáson” alapul. Érdemes volna tehát a kis tradícióra jellemzô terjedési mechanizmus esetében a mém analógiát használni, amely így tehát inkább a kultúrában vertikálisan, öntudatlanul terjedő jelenségeket jelölné. Ezzel szemben Sperber elméletében a pszichikus változásokra, a tudatosságra helyeződik nagyobb hangsúly, a vírus analógiát ennek megfelelôen inkább a kultúrában horizontálisan, gyorsan terjedô jelenségek leírására használhatnánk, ami fóként a nagy tradíciók jellemzője. Így a kis és nagy tradíció fogalmaihoz egyegy rájuk jellemzőbb terjedési elméletet kapcsolhatunk. Ugyanakkor újra hangsúlyozni szeretném, hogy itt csupán egy elnagyolt modellrôl van szó, hiszen mindkét típusú terjedési mechanizmus megtalálható mind a kis, mind pedig a nagy tradíción belül is. Csupán az arányokban fellelhető különbség teremti meg a kategorizáció lehetőségét.

Függetlenül azonban a kis és nagy tradíció elméletétôl, még egy megjegyzést kell tennünk a mém kontra járványtan analógiához: a kultúrák egy hosszabb időn keresztül stagnáló, vagy alig változó típusainál nehéz a járványtani analógiát használni. Azaz ennek a használata éppen olyan korlátozott lehet mint a memetika. Hosszabb idốn most azt értem, hogy adott kultúra a maga egész élettartama alatt vagy semmit, vagy csak minimálisat változik, akkor is csak külső hatásra. Ilyenek a természeti népek pl. bushmanok vagy az ausztrál bennszülöttek. Ha hihetünk a régészeti emlékeknek, akkor ezek a kultúrák maguktól semmit sem változtak. De hogy ne csak általánosságban beszéljünk, nézzünk egy konkrét példát: Egyiptomban, a keleti sivatagban látható sziklarajzok esetében komoly problémát jelent a kutatók számára azok datálása. A figurális ábrázolások zöme egyaránt lehet őskori, antik, „csupán” pár száz éves, vagy akár recens. Ráadásul nem pusztán a formavilágukat, de készítési módjukat tekintve is. (Ezeknél a rajzoknál a datálás egyetlen alapja csak a patina lehet.) Az afrikai sziklarajzok bár pontos, de spontán replikációk. Vannak azonban a kultúrában olyan jelenségek is, ahol a precíz átadás kényszerítve van. Például a rítusok esetében, ahol pontosan meghatározott módon kell eljárni. Ezekben az esetekben nincs értelme járványról beszélni, inkább memetikai ismétlődésrôl. A terjedési mechanizmusok sokféleségére Sperber is felfigyelt. Éppen ezért a különbözố terjedési mintázatokat más és más betegséghez hasonlította (pl. malária, tüdôrák, vérszegénység). „A reprezentációk például különböző módon lehetnek kulturálisak. Vannak köztük olyanok, melyek lassan terjednek a nemzedékek között. Ezeket nevezzük hagyománynak, s ezek hasonlítanak az endémiákhoz. Más reprezentációk, melyek a modern kultúrára jellemzőek, igen gyorsan elterjednek egy egész populációban, élettartalmuk azonban igen rövid - ezeket nevezzük divatoknak, s ezek hasonlítanak a járványokhoz" (Sperber, 2001:84). Az endémia a járványok azon típusa, ami egy bizonyos területen belül szokásosan elôfordul, azaz otthonos az adott területen. Így például a malária, vagy az AIDS Afrika bizonyos pontjain. Ez az analógia azonban csak annyiban találó, amennyiben egy adott hagyománynak is megvan a maga területe (mondjuk a buddhizmusnak Kelet). Ha azonban a terjedési mechanizmust nézzük, és ha következetesek akarunk lenni Sperber elméletéhez, akkor ezt kell tennünk, rögvest kitúnik, hogy a járvány attól még járvány marad, azaz egy viszonylag gyors, horizontális terjedésû folyamat, ami semmiképpen nem jellemzi a generációkról generációkra szálló hagyományokat. A kevéssé változó formák apáról fiúra öröklődő vertikális terjedése sokkal inkább a gén-analógia használatára ösztönöz. 
Sperber epidemiológiai és Dawkins memetikai elmélete azonban összebékíthetô. A biológiai alapokat zárójelbe téve, tekintsük a lokális kultúrát élő szervezetnek, amely ki van téve különböző fertőző betegségek, azaz a hódító eszmék veszélyének. A metaforikusan értendő vírus lényege az eszmék (hittételek, világképek, stb.) valódi szemantikai tartalma. A kis tradíció a kulturális immunrendszerrel áll szoros összefüggésben. Amikor a vírus behatol a szervezetbe, megpróbálja azt átalakítani, pontosabban, amint már fentebb szó volt róla a létező formákat kisajátítani. Ha ez sikerül, a gazdaszervezet belehal. Így irtotta ki például az Iszlám a Közel-Kelet ôsi kultúráit. Igaz ugyan, hogy korábban már a későantik világ multikulturalizmusa fellazította ezeket a kultúrákat, tehát egy legyengült gazdaszervezetről volt szó. Először a hellenizmus, majd a kereszténység támadott, végül az iszlám vitte tökélyre a pusztítást. (Ez arra is tanulság, hogy rendszerint egyetlen rohamra nem pusztul el a gazdaszervezet.)

A másik lehetôség (és ez a gyakoribb), hogy egyáltalán nem pusztul el a szervezet. Ilyenkor a hódító eszme, illetve a nagy tradíció semmisül meg. Az esetek többségében ilyenkor kivonul az adott területrốl, illetve nem tudja megvetni a lábát ott (pl. a buddhizmus kiszorult szülőhazájából, Indiából). Gyakran azonban azáltal heveri ki a fertôzést egy adott organizmus (lokális kultúra), hogy magába integrálja annak információtartalmát, mintegy magához idomítja azt. Amikor tehát a hódító eszmék elterjednek a kultúrában és idôvel tudattalanná válnak, kiüresednek, nos ez az eszme szempontjából „rossz”, ám a lokális kultúra szempontjából „jó”, hiszen a vírus elveszítette "mérgét”. (Mint az említett tibeti buddhizmus, a helyi kultuszok, népi vallásosság a katolicizmusban, stb.) Minden esetben egy fertőzés történt, amit ily módon az adott lokális kultúra kihevert - igaz bizonyos átalakulások árán.

A nagy tradíció sokszor képes a megújulásra (vallási, ideológiai reformok). Ez lényegében a vírus mutációja, amely látszólagosan a fennálló nagy tradíciót támadja, valójában azonban a gazdaszervezetet. Így például az eretnek mozgalmak zöme látszólag a katolicizmust támadta, ám valójában a társadalmi rendet bomlasztották, hiszen a köznapi élet szintjéig át akarták alakítani a kultúrát. Ebben rejlett fô veszélyességük (melyet az intelligensebb inkvizítorok pontosan tudtak, ezért küzdöttek olyan elszántan ellenük).

A kis tradíció/nagy tradíció viszony vagy dualitás a kultúrában tehát a betegség megfelelôje. Azé, ami nem halálos, ám meghatározza a megtámadott szervezet múködését, lehatárolja annak mozgását, szabadságát, új keretet ad neki (miként a középkorban a filozófia is csak a teológián belül múködhetett, a szocializmus idején írt könyvekhez pedig hozzá kellett csapni a „vörös farkat”).

Dan Sperber elméletében a járványtani metafora - mint arra Pléh Csaba is felhívta figyelmünket - nem azt a negatív asszociációt hordozza, amelyet a köznapi kommunikációban, illetve a társadalomtudomány számos régi elméletében megszoktunk, azaz nála a fertôzésanalógia elveszíti negatív felhangjait, és a gondolatok terjedésének általános modelljévé lesz. Mindazonáltal egy ilyen analógia használata óhatatlanul felveti a kérdést: mi az egészséges egy kultúra esetében? Anélkül tehát, hogy bármiféle értékítéletet csempésznénk vissza az elméletbe, annak sajátos logikájából következóen egészségesnek egy autonóm kultúrát tekinthetünk, egy egységes, koherens rendszert, amelyben megszűnik a kis és nagy tradíció kettôssége, ahol is a rendszer önfenntartóvá válik, és saját maga termeli ki a létfenntartásához szükséges tudatos magyarázatokat. 
A járványtani analógia segítségével a Redfield által megemlített jelenségek mellett más jelenségek is új megvilágításba kerülhetnek. Így például értelmet nyerhetnek olyan fogalmak, mint a kultúrák elöregedése, kultúrák regenerációja, avagy az intolerancia, mint védekezố mechanizmus, stb. Az immunrendszer múködésének további jó példáját nyújtja a szakember mítosza, amely korunk egyik alapmítoszává vált szemben a megelôzô évszázadok zseni- és polihisztor-kultuszával. „Emberi szempontból” a szakmai szigor a zsenialitás, a kreativitás, a fantázia és az intellektuális nagyvonalúság ellentételezése, a középszer kultusza. Ugyanakkor ez egy szabályozó rendszer: a kultúra ugyanis képtelen lenne elviselni a zsenialitás és az információs robbanás találkozása adta minőségi ugrást. E kettő kereszteződése szétvetné a kultúrát. Nem véletlen, hogy a szakember-mítosz egyidőben jelenik meg az információs robbanással. Az sem véletlen, hogy a zseni-mítosz még ez elôtt az információs robbanás előtt dívott.

\section{Kísérlet a redfieldi elmélet kiterjesztésére}

Továbbiakban egy konkrét esettanulmányban összegezzük az eddigieket. Láttuk, hogy a redfieldi kis tradíció/nagy tradíció fogalompár segítségével érzékletesen megragadható egy adott kultúrán belül a hagyományos vallásosság, illetve az elit által képviselt eszmék közötti különbség, illetve a kettôjük viszonyrendszere. A kis és nagy tradíció jellemzôi azonban nem csupán a vallásosság dimenziójában érvényesek, hanem kiterjeszthetốk más kulturális jelenségekre is, így például a politikai ideológiák világára. Ráadásul - és ez megkönnyíti Redfield elméletének kiterjesztését - a politikai ideológiák fenomenológiailag és funkciójukat tekintve is sok ponton rokoníthatók a vallással, noha természetesen egészen más kulturális rendszert alkotnak (Durkheim, 1915).

A kis és nagy tradíció kettôsségének egyik legjobb példája a politikai ideológiák terén a marxizmus. Már a poszt-sztálinista idôszak egyik közhelye volt marxista teoretikusok, illetve politikusok nyilatkozataiban, szólamaiban, cikkeiben, hogy a szocializmus minden országban a helyi sajátosságoknak megfelelően fejlődik, illetve, hogy nemzeti arculatot ölt. ${ }^{11}$ Úgy tudom eme jelenségnek tudományosan kidolgozott teóriája nincs, ám a témával foglalkozó csaknem minden jelentősebb kutató megemlékezett róla, a politikusok pedig teljes természetességgel dolgozták be beszédeikbe. Ami a kommunisták részérôl pozitív előjelű ténymegállapításként hangzott, a létezố szocializmus kritikusai szájából, tollából pejoratív hangvétellel fogalmazódott meg. Az utóbbiak olyan jelenségként kezelték, amely rávilágít a létezô szocializmus álságos mivoltára, elmaradottságára, sốt számukra majdhogynem minden hiba forrásává vált.

Mirôl is van szó? A kínai típusú szocializmus valójában nem más, mint marxista köntösbe öltöztetett ázsiai termelési mód, illetve az ősi császári Kína továbbélése, ami a paraszt társadalomtól kezdve a kultúra egészére igaz lehet. Jordán Gyula a Mao körül kialakult személyi kultuszról a következőket írja: „A rendszer legitimitását erősítette az a tisztelet és kultusz, amit a tekintélyelv sok évszázados hagyományaira is építve Mao körül kialakítottak. (...) Az egyszerú átlagpolgárok számára ugyanolyan felfoghatatlan távolságban és mindenféle feltételezésektől övezve helyezkedett el, mint régen a császár, így a kommunista propagandának semmiféle erôfeszítést nem kellett tenni, hogy az »Ég fia« körül évszázadok alatt kialakult tiszteletet a megvál- 
tozott körülmények és frazeológia ellenére átvigyék Maora” (Jordán, 1999:194). Példák tucatjait sorolhatnánk még arra vonatkozóan, miként jelentkezett, élt tovább az ősi kultúra, mint kis tradíció a térségben: történetek egész sorát hallhatjuk túlélő visszaemlékezóktől pl. a kulturális forradalom idejéből, hogy egyes kínai falvakban teát fő́ztek a párttagkönyvekbôl, amelyet a fej alá kellett tenni, hogy segítsen a betegségek megelőzésében, vagy amolyan amulettként alkalmazták. Sốt, még az emberáldozat is megjelenik: egy faluban megöltek egy burzsoá leszármazottat és a szívét rituálisan megették. A keleti típusú szocializmus egyik élô múzeuma ma Észak-Korea, ami sokkal inkább közösségi tulajdonon (azaz ázsiai termelési módon) alapuló szakrális istenkirályság, mintsem a Marx által megálmodott fejlett szocialista társadalom.

Majdhogynem közhely, hogy a sztálini Oroszország sok szempontból - a forradalom rövid szünete után - a cári félfeudális, prekapitalista rendszer továbbélése. Sztálin, a népek atyja inkább volt keleti uralkodó „igazi atyuska”, mintsem a proletariátus élcsapatának vezére (Deutcher, 1990; Krausz 1996, 1997; Daniels, 1990; Gill, 1990). A kolhozosítás valójában a régi paraszti földközösség, az obscsina visszahozása volt, pontosabban ideológiai köntösbe öltöztetett megmentése attól a Nyugatról jött kapitalista fejlődési mintától, ami a századfordulóra Oroszországot is elérte.

Romániában a régi vajdák és a fanarióta uralom reneszánsza volt a Ceausescu rendszer. De hogy egy kicsit saját házunk táján is sepregessünk: egy itthoni szocialista faluban az emberek úgy voltak párttagok, mint ahogy templomba jártak régen. A keménykezű rendőrt semmi sem különböztette meg a csendőrtől, ahogyan a dzsentri-mulatozások is átmentôdtek a felsôbb pártvezetés köreibe vadászattal összekötött gulyás-partik formájában.

Ezek persze csupán kiragadott példák, amelyekkel érzékeltetni akartam, miról is van szó: a kultúra alárendelődött ugyan egy nagy tradíciónak, ámde mégis legyőzte, magába integrálta azt. A leglátványosabb példája ennek az elvnek Afrika, ahol a régi törzsi ellentétek osztályharcok ideológiai örve alatt folytatódtak tovább. A Szovjetunió és a többi szocialista ország által támogatott helyi felszabadítási mozgalmak már a kezdet kezdetétől a helyi törzsi viszonyokat vették alapul, és erre épültek azután a késóbbi szocialista kísérletek, amelyekben az ôsi földközösségek, vagyonközösségek eszméje tér vissza a marxizmus nevében. Ez volt az ún. „törzsi szocializmus”, (amelyen Európában még a kritikusabb marxisták is mosolyogtak).

A létezô szocializmus esetében látjuk tehát a kis tradíció/nagy tradíció kettôsségének meglétét, a globális hódító eszme és a lokális kultúra közti ellentmondást, ami a kis és nagy tradíció kettősségében sajátos szimbiózisba kerül egymással. Az ellentmondás tehát csak látszólagos, mivel a szimbiózisban nagyszerủen megférnek egymás mellett. Vagyis Kínában, Afrikában és Oroszországban, de részben Kelet-Európában is a régi viszonyok - nyugodtan mondhatjuk a régi kultúra - háborítatlanul tovább élt volna a forradalmi eszme keretei között is.

A marxizmus, mint nagy tradíció, mint globális eszme mindenhol, ahol megjelent a lokális hagyományokhoz illeszkedett. Ebben az esetben azonban lokális hagyományt már nem feltétlenül egy falu képvisel, hanem egy helyi kultúra. Lokális az, ami szembefordul a globálissal. A két fogalom csak az egymáshoz való viszonyukban értelmezhetố. Voltaképpen ugyanaz a kultúra egyaránt lehet lokális és globális is: például a kínai szocializmus lokális a marxizmus általános eszméjéhez képest, ám globális a kínai falvakban megvalósuló formákhoz képest. 
De menjünk tovább és nézzük meg a memetikai/epidemiológiai analógia segítségével, mi is történt „valójában”? Megjelenik egy hódító, új eszme, amely mintegy vírusként megtámadja az adott lokális kultúrát. Ez a marxizmusnak az az idôszaka, amikor mint igazi forradalmi eszme mindent meg akar változtatni, azaz Oroszországban az 1914-től 1924-ig terjedó idôszak, nálunk inkább az ötvenes évek. Kínában a folyamat sajátossága miatt más modell érvényesült, mert ott a maoizmus a kulturális forradalommal teljesedik ki. A történelem, illetve a politika nyelvén egy konszolidációs időszak következett be. Valójában azonban, ami a politikában konszolidációs időszak, az a kultúra szempontjából az adott lokális kultúra védekezése a behatolóval szemben, feléledése, egyfajta visszatalálása önmagához, ahhoz hasonlóan, mint amikor egy immunrendszer ellenanyagot termel. Ekkor áll be a kis és nagy tradíció kettősségének időszaka. Az explicit tartalmat a marxizmus mint nagy tradíció képviseli. A kis tradíciót a régi szokások, a mentalitás, a hagyományok, a gondolkodásmód alkotják, amelyek mintegy keretet adnak a nagy tradíció (létezố szocializmus) kibontakozásának.

A marxizmus a „kulturális immunológia” szempontjából különösen hálás példa, ugyanis egy duplacsavar rejlik benne, ami túlmutat a szimpla kis tradíció/nagy tradíció kettősségen. Ha távolról nézzük azt, ami az elmúlt száz évben történt az ún. létező szocializmus kapcsán, akkor egy sokkal bonyolultabb képet és egészen megdöbbentô eredményt kapunk. A marxista ideológia szinte a legtöbb helyen, ahol uralkodó ideológiává vált és létrejött a szocialista társadalom, nem egyszerúen egy ezekbe a régiókba avagy lokális kultúrákba behatoló és azt átmenetileg uraló idegen kulturális rendszer volt, hanem egy olyan „betegség”, amely védelmet nyújtott az adott kultúra számára egy sokkal súlyosabb betegség, egy halálos kor: a globális kapitalizmus, azaz ezekbe a kultúrákba behatoló nyugati fejlődés modell (és annak kultúrái) ellen.

Ezek a kultúrák ugyanis a szocializmus révén lettek önállóak, találtak vissza önmagukhoz és álltak ellent a hódító Nyugatnak. Méghozzá nem egyszerúen politikai téren. Nem csak arról van szó, hogy Kína vagy az afrikai régiók lettek függetlenek, vagy Oroszország a sztálinizmus révén lett világhatalom (persze ez is), hanem, hogy a régi orosz, kínai, koreai, afrikai, stb. hagyományok, mentalitás maradtak fenn a szocializmus révén. Azok a kulturális sajátosságok, amelyeket a nyugati kapitalista fejlődés elpusztított vagy sokkal inkább megváltoztatott volna. Habár a szocializmus ezeket megbolygatta, sốt látszólag óriási pusztítást vitt végbe (templomok lerombolása, a paraszti társadalomba való beavatkozás, eróltetett iparosítás, a kulturális forradalom tradicionális kultúrát romboló hatásai, stb.), valójában ezeket lejegelte. ${ }^{12}$ Hasonlóképpen ahhoz, ahogy az Oszmán birodalom a Balkánt lejegelte és tartósította. A kulturális produktumokat szétzúzta, ám a kultúra gyökerét, a gondolkodásmódot mégis életben tartotta, mi több megerôsítette. Így a marxizmus egy olyan szérumhoz hasonlítható, amelynek a mellékhatásai ugyan szörnyúek, ám az életben maradást szolgálja.

Külön figyelmet érdemel, hogy az említett „káros mellékhatások”, a tradicionális kultúra rombolása a konszolidáció elôtti átmeneti időszakhoz, a forradalomhoz kapcsolhatók. Azután, az azt követő sztálinizmus és a többi hasonló „helyi sajátosságokat” felvevô szocializmus bizonyos ôsi kulturális formákat kifejezetten favorizált. Gondoljunk például a népmúvészet, illetve a népzene támogatottságára. (Szemben azzal, ami alternatíva kívánt lenni: az olyan dekadens nyugati kulturális termékek, mint a rockzene, a jazz, stb.) 
A dolog bonyolultságát mi sem mutatja jobban, mint a már említett obscsina példája: A prefeudális, félig-meddig az ázsiai termelési mód fogalomkörébe sorolható régi orosz tradicionális paraszti földközösség a XIX. század végén kezdett megbomlani a lassan kialakuló orosz kapitalizmus hatására. Kialakult egy módosabb agrárkapitalista, paraszti vállalkozó réteg. Ezt a fejlôdést akasztotta meg a forradalom, illetve a hadikommunizmus. Majd miután az nem müködött, Lenin meghirdette a NEP-et (amit a balos utópisták rekapitalizálódásnak minősítettek). Ennek vetett véget a sztálinizmus az erôszakos kolhozosítással, ami voltaképpen nem volt más, mint a régi obscsina feltámasztása. ${ }^{13} \mathrm{~A}$ folyamat lényegét G. P. Fedotov foglalta össze aforizmatikus tömörséggel: „A kalapács összezúzta a sarlót, hogy traktort készítsen belőle” (Fedotov, 1992:18). Mi történt tehát? A marxizmus, mint nagy tradíció elsố látásra úgy tûnik, hogy tudatosan, felülrôl vezérelve alakította ki a gazdaságot, valójában - távolról nézve - azonban a marxizmus leple alatt az ősi kultúra regenerálódott. Itt tehát nem a gazdaságról van szó, hanem az életmódról. A marxizmus egy erôszakos ideológia nevében beleszólt a gazdaság múködésébe, az emberek életébe, de a kultúra szempontjából eme tudatos aktus valójában csupán látszat, mert a kultúra tudattalan önalakításáról, pontosabban regenerálódásáról beszélhetünk. ${ }^{14}$

A létezố szocializmus kérdése persze rendkívül bonyolult és összetett, és sok esetben valóban a modernizációt szolgálta. Véleményem szerint azonban a létezô szocializmus megítélésében ez csak másodlagos szempont, a modernizáció a kultúrával kapcsolatban inkább csak bizonyos külsôségekben nyilvánult meg. Valójában az adott kultúra rearchaizálása volt a kapitalizmus által reprezentált nyugati kulturális behatással szemben. Vagyis a létező szocializmus olyan jelenségei, mint a társadalmi mobilitás, illetve az ezzel együttjáró olyan kísérôjelenségek, mint a címek és rangok megszűnése, mint az iparosítás és az indusztriális kultúrával megjelenố futurisztikus elképzelések favorizálása, stb. a kultúra szempontjából, pontosabban a kultúra mélyrétege szempontjából, amit az adott kultúrát alkotó egyének és csoportok mentalitása reprezentál, csupán másodlagos jelentôségú. Az olyan, szinte toposznak számító nézetek, mint a lenini, sztálini, stb. rendszerek az ázsiai termelési mód (illetve Európában a feudális struktúra) a kultúra e mélyrétege szempontjából inkább fontosak, mint a szocializmus alatt végbement modernizáció. Ezzel természetesen lehet vitatkozni, viszont a dolgozat keretei nem adják meg a lehetôséget ennek kimerítô elemzésére, így ez a jelen kontextusban megmarad a redfieldi modell kiterjesztését illusztrálandó munkahipotézis szintjén. ${ }^{15}$ Egyébként, ha e nézetem egyáltalán nem volna helytálló, a létezô szocializmust megvalósító országok (térségek) ősi kultúrái archaikus elemeinek továbbélése akkor is kétségbevonhatatlan tény. Ennélfogva a redfieldi modell mindenképpen alkalmazható akkor is, ha a fenti munkahipotézis alapjaiban elhibázott lenne. Itt ugyanis ugyanazzal a kettôsséggel állunk szemben, mint a már említett példák esetében, azaz létezik egy lokális kultúra a maga ôsi mentalitásával, amelyre rátelepedett egy nagy, lokális határokon átlépő, univerzális, globális igényekkel fellépố eszmerendszer a marxizmus, illetve ennek lenini, sztálini, maoi formái. Így e fenti rész a redfieldi modellrôl szólt, nem pedig a létezó szocializmus(ok) kimerítô elemzése kívánt lenni.

A létezô szocializmus példája tehát azt mutatja, hogy függetlenül az egyéni szándékoktól, történelmi beágyazottságtól, úgy is szemlélhetjük a kultúrákat, mint önálló, önszerveződő organizmusokat. De hozzunk egy másik szemléletes példát egy 
egészen más területről: miután a protestantizmus - katolicizmus földrajzi határai letisztázódtak, a térképen nagyjából a hajdani Nyugat-Római Birodalom határai rajzolódtak ki. (Az anglikán terület is katolikusnak tekinthetố a kultúra szempontjából, hiszen a pápai fennhatóságon kívül minden másban megmaradtak a katolikus jellemvonások.) Történetileg persze minden egyes ország esetében lehetne racionális érveket hozni, arra vonatkozóan, hogy miért lett az adott ország inkább a katolicizmus avagy a protestantizmus otthona. ${ }^{16}$ Ám távolról nézve egy emberen túli képet kapunk, amelyben a kultúra, mint élő szervezet jelenik meg.

\section{Kísérlet a kulturális változások tipizálására}

Úgy tûnik, az analógiák a vizsgálódás eddigi szintjén múködnek. Mindazonáltal nem elégedhetünk meg ennyivel, hacsak nem akarunk a felszínes gondolkodás zsákutcájába jutni. Ahhoz, hogy a terjedés-elméletekrôl pontos és releváns megállapításokat tehessünk, a kulturális folyamatokat, változás-típusokat mélyebb analízis alá kell vetnünk. A reprezentáció-terjedés elméleteivel - különös tekintettel a mém-elméletre - szemben azt az ellenérvet szokták felvetni, hogy nehezen meghatározható az a kulturális egység, amelynek az öröklôdésérôl szó van. Dawkins például egyaránt mémként kezeli a boltívet, a dallamokat, az eszméket és a vallásokat is, azaz az egészen egyszerű (még önállóan megjegyezhető) egységeket csakúgy, mint egész eszmerendszereket (Dawkins, 1986). Susan Blackmore úgy próbál finomítani az elképzelésen, hogy az összetettebb jelenségekre a „mémplex” elnevezést használja (Blackmore, 2001). Ezek tehát mémek társulásai, amelyek egymást segítik az öröklődésben. Látnunk kell azonban, hogy ez a megoldás sokkal inkább elfedi a problémát semmint feloldja. Ha kijelentjük mondjuk a vallásokról, hogy azok mémplexek - ahogyan Blackmore teszi - akkor egy elemzési szinttel feljebb kerülünk, ahol már képtelenség annak az elemzésése, hogy voltaképpen milyen mémek azok, amelyek összeálltak egy viszonylag egységes rendszerré. Honnan „ismerik fel” egymást az összetartozó mémek? Vagyis mitôl összetartozóak egy mémplexen belül? Ez a kérdés különösen azokban az esetekben fontos, amikor azt látjuk, hogy például egymással látszólag inkonzisztens eszmék állnak össze egy koherens rendszerré. A memetika egyik fontos feladata pedig éppen az lehetne, hogy ezen társulások belsó logikáját felfedje. Lássunk két esetet: például a hazai közéletben, az SZDSZ holdudvarát alkotó liberális értelmiségiek körében a szegények, a hajléktalanok, az elesettek egy sajátos kultusza figyelhetô meg. (Ezzel függhet össze, hogy - legalábbis eddigi megfigyeléseim szerint - a szociális munkások körében az elmúlt években igen népszerú volt az SZDSZ.) Ez azért különösen érdekes, mert a párt kezdettől fogva a szabadversenyes kapitalizmus elsố számú hirdetôje volt a hazai pártok között. Hogyan kerülhet össze ez a kétféle beállítódás? Az ellentmondás könnyen feloldható. Ugyanis, ha a szegénység SZDSZ-féle értelmezésének mélyére ásunk, azaz e probléma liberális megjelenítéseit annak kontextusában szemléljük, hamar kitûnik, hogy náluk e fogalom korántsem a hagyományos baloldali jelentést hordozza, hanem egy kulturális kategóriává válik. Náluk a szegénység voltaképpen a „másság”, ill. a „kisebbség” fogalmaival ekvivalens, pontosabban: ez utóbbiak egyik formájaként jelentkezik. Így a hajléktalanok, vagy éppen a kisnyugdíjasok egy kalap alá kerülnek a melegekkel, a leszbikusokkal, az 
elnyomott nőkkel, stb. (A romákról már nem is szólva, akik ily módon kétszeresen „mások”, ill. „kisebbségiek”.) A „kisebbség” és az ebből adódó „másság” védelme pedig az emberi jogok, vagy méginkább: az egyén jogainak, az individualizmusnak filozófiai talaján fogalmazódik meg. Ennélfogva tehát a „liberális szegénykultusz” nem hordoz magában antikapitalista tendenciákat, mivel végsố alapja ugyanaz, ami a szabadversenyes kapitalizmusé: az individualizmus. Látjuk tehát, hogy egy mémplex mélyebb elemzése egészen új összefüggések megvilágítására alkalmas, és feloldhatja a látszólagos ellentmondást.

Nézzünk egy másik példát is erre, a látszólagos összeférhetetlenség ellenére létrejött társulásra: aki ma Magyarországon, ill. valamely nyugati országban buddhistának vallja magát, és tagja is egy ilyen közösségnek, az rendszerint elfogadja az okkultizmus számos más irányzatát is. Így egy valamirevaló buddhista hisz az asztrológiában, az aurában, a természetgyógyászatban, a telepátiában, stb. Mondanunk sem kell, hogy a buddhizmus eszméjének ezekhez az okkult irányzatokhoz semmi köze nincs, mégis összetársultak, s ennek révén együtt „öröklődnek” nyugaton. ${ }^{1718}$ Egy vizsgálat során természetesen itt is ki lehetne mutatni, mi az, ami összeköti ezeket az eszméket.

Ha tehát a hagyományok öröklôdésérôl beszélünk, fel kell bontanunk ezeket a mémplexeket alkotóelemeikre, hogy megérthessük az öröklôdés mikéntjét. A teljesség igénye nélkül vizsgáljunk tehát meg néhány általánosan ismert kulturális jelenséget - amelyek mindegyikében valamiféle öröklődésről beszélhetünk - abból a szempontból, hogy milyen változás-típus jellemzi, vagyis az adott kulturális folyamat során pontosan mi is az, ami öröklődik, és mi az, ami változik. Egyáltalán milyen értelemben beszélhetünk változásról? A néprajzból oly jól ismert survival esetében például bizonyos kulturális formák, mint puszta formák élnek tovább egy megváltozott értelmezési kereten belül. (Bon hagyományok és istenek a buddhizmusban, pogány istenek keresztény szentekként, stb.) Vagy nézzük az ún. „gesunkenes Kulturgut” jelenségét, amikor az elit kultúra produktumai egy idô után - többnyire elsố közegükben történt „elhasználódásuk” után - mintegy „lecsöpögnek” az alsóbb társadalmi rétegek kultúrájába, persze ennek révén bizonyos változásokon mennek keresztül. (Ilyen például az, amikor a polgári szalonokból tisztaszoba lesz, vagy a nemesi viseletbôl paraszti öltözet, vagy nyugatias hangzású neveket adnak alsóbb társadalmi rétegek szülötteinek, stb.) Nos, itt már bonyolultabb a helyzet, mivel továbbélnek ugyan a formák, ám meg is változnak. A szalon és a tisztaszoba a funkciójában megóriz valami azonosat, ti. a reprezentáció célját szolgálja, ám amíg a polgári szalon a lakás szerves része volt, azaz használták a mindennapi élet során (a vendégeket ott ültették le, stb.), addig egy parasztház tisztaszobája kívül esett az élettéren, kizárólag reprezentációs célokat szolgált. Beszélhetünk továbbá egy bizonyos kulturális elem adaptációjáról, amikor például egy városi kisgyerek barbie-babákkal játssza el a betlehemest karácsonykor. Vagy amikor egy őserdei törzset arra kényszerítenek, hogy egy városba beköltözzön, és a törzs továbbra is megtartja szokásos ünnepeit, ám most már nem gombából főzött itallal érik el a bódult állapotot, hanem mondjuk sört isznak a rítus során. Ezekben az esetekben a rítus tartalma és funkciója azonos maradt, ám a forma változott. Adott esetben egy-egy kulturális elem álcáaását figyelhetjük meg. Napjainkban az okkultizmus mint ál-tudomány jelenik meg: átveszi a tudományos szóhasználatot, eszközöket (például a természetgyógyász is fehér köpenyt ölt), stb. Ilyenkor a tartalom megváltozik (tudományosból áltudományossá válik), ám a forma (tudományoskodás) és bi- 
zonyos szempontból a funkció (gyógyítás) azonosnak tekinthetô. A revival azt a jelenséget jelöli, amikor valamilyen hagyományt mesterségesen újra felélesztenek (pl. táncház-mozgalom). Ez utóbbi azért is érdekes jelenség, mivel itt éppen a gesunkenes Kulturgut ellenkezőjéról van szó: az elitkultúra fedez fel valamit a népi kultúrából, és konstruálja újra azt. Megemlíthetjük továbbá a mitizálódás folyamatát (amikor egy egyszerú történetből, vagy történeti eseményből mítosz lesz), vagy ennek rokonát, a sæimbolizációt (pl. a kereszt, ami kivégző eszközből szakrális szimbólummá vált). Megint más típusú kulturális változás, amikor egy adott tárgyat vagy eszmét a kényszerítő körülmények hatására vagy a kecsegtető haszon reményében más célra használnak, mint amire az eredetileg való. (Pl. amikor politikai ideológiaként használnak fel egy tudományos eszmét, vagy a papírhiány miatt könyvekkel gyújtanak be.) Ezekben az esetekben a tartalom (az eszme jelentése) és vele együtt a funkció (amire használják) megváltozik, ám a forma megmarad. Sorolhatnánk még tovább a példákat, ám ennyibôl is kitetszik, mennyire összetett problémával állunk szemben.

A pontosabb megragadhatóság érdekében, - mintegy munkahipotézisként - a példák alapján úgy tűnik, érdemes bevezetnünk a forma, funkció és tartalom hármas kategóriáját a kulturális jelenségek vizsgálatában. Természetesen tisztában vagyok vele, hogy ezek megkérdôjelezhetố fogalmak, amelyeket a különbözố szakirodalmakban, társadalomtudományokban többféle értelemben használnak. Éppen ezért röviden összefoglalom, miként is értelmezzük ezeket a jelen kontextusban. A forma voltaképpen a megjelenés. Egy tárgy alakja, egy rítus elvégzésének módja, egy eszme „szemantikai burka", azaz leírása, a szóhasználat, a stílus, és a szerkezet, azaz megjelenítésének módja. A funkció még problémásabb fogalom. Az antropológiában kettős értelemben ismert, főként Malinowski és Radcliffe-Brown munkássága nyomán. Míg Malinowski az emberi szükségletekból indult ki, kollégája a struktúrában - amelyet az élő organizmusokhoz hasonlított - betöltött szerepre helyezte a hangsúlyt. Például, ha a vallás fö funkciójaként a nyugalmat, a békét tekintjük, akkor Malinowski megközelítésével azt mondhatjuk, hogy annak funkciója a lelki béke az egyén számára. Ám ha ezt Radcliffe-Brown szemüvegével nézzük, akkor inkább azt mondhatjuk, hogy a vallás funkciója a társadalmi béke fenntartása. (Persze ezt csak a példa érthetôsége kedvéért írom, a vallás tényleges funkciójához ennek semmi köze, hiszen jóval bonyolultabb kérdés.) Egyelốre azonban ne menjünk bele ilyen finom megkülönböztetésekbe, hanem a funkció szót annak hétköznapi értelmében használjuk. (A pénz funkciója a fizetés.) Ugyanakkor nem zárhatjuk ki annak a lehetôségét, hogy a további elemzés során mégis szükségesnek látszik majd a pontosítás.

A három kategória segítségével felállíthatunk egy tipológiát, amely segíthet rávilágítani arra, mikor is beszélhetünk „memetikai öröklődésrôl” és mikor egy „vírus terjedésérôl":

\begin{tabular}{l|c|c|c|c|c|c|c|c|} 
& 1. & 2. & 3. & 4. & 5. & 6. & 7. & 8. \\
\hline tartalom & + & - & + & - & - & + & + & - \\
\hline forma & + & - & - & + & - & - & + & + \\
\hline funkció & + & - & - & - & + & + & - & +
\end{tabular}

(+ : változás; - : állandóság;

Az 1-tốl 8-ig terjedố számok a típusokat jelölik.) 
Az első esetben a tartalom, a forma és a funkció is megváltozott. Ez lényegében egy kulturális jelenség teljes eltûnését jelöli. Példa: Az iszlám kiszorította a Közel-Kelet antik kultúráját, szinte nyomtalanul eltörölve azt.

A második típusban sem a tartalom, sem a forma, sem pedig a funkció nem változik. Példa: az ausztrál bennszülöttek már említett sziklarajzai. Lényegében ide sorolhatók a nem változó kultúrák produktumai.

A harmadik oszlop azt jelöli, amikor egy kulturális tartalom megváltozik, viszont a forma és a funkció változatlan marad. Példa: Anubiszból Szent Kristóf lett, azaz az egyiptomi hitvilágot felváltotta a kereszténység (tartalom), az alak ábrázolása illetve a vallásban betöltött funkciója viszont lényegében megmaradt. További példák: Jézus szíve körmenet helyett Marat szíve körmenetet tartottak a francia forradalom idején; amulettek helyett a Vörös Könyvecskét használták Kínában mindenféle gyógyításra.

A negyedik változatban a forma megváltozik, míg a tartalom és a funkció továbböröklődik. Példa az UFO-hit, ami voltaképpen modern, technicizált démonhit. A démonokból UFO lett (forma), viszont a tartalom, miszerint az emberek felett jó vagy rossz indulatú félisteni lények léteznek, amelyek elrabolják vagy segítik ôket, lényegében nem változott, csakúgy, mint a hit funkciója sem, ami a kapcsolatfelvétel lehetôsége ilyen lényekkel. További példa: a rubel, amely nevében is ôrzi, hogy eredetileg ezüstrúd volt, majd később változott érmévé, illetve papírpénzzé.

Az ötödik variációban csupán a funkció változik, ám a tartalom és a forma változatlan marad. Példák: formálissá váló vallási elemek, amelyet leginkább a nagyegyházak és a szekták különbsége szemléltet. A nagy egyházakban inkább kulturális tradíciót ápolnak, (nem véletlen pl. a „történelmi egyház” elnevezés) míg a szektákban a vallásos érzület a domináns elem. (Ez persze nem jelenti azt, hogy ne jelenhetne meg a vallásos érzület a nagyegyházakban, vagy valamely hagyomány ápolása a szektáknál, itt arról van szó, hogy mi jelenti ezen intézmények kulturális lényegét.) További példák: egy vallási eszméből politikai ideológia lesz (pl. politikai kereszténység), használati tárgyakból dísztárgy vagy értéktárgy (régiségek, tányér a konyha falán, bélyegek és érmék gyưjitôk számára, stb.).

A hatodik típusban a tartalom és a funkció változik meg, a forma azonban továbbra is fennmarad. Példa: valamely használati tárgyat utánzó dísztárgy, amit már nem a funkció alapján nevezünk el. Fớképpen a giccs területén találkozunk példákkal - ilyen egy pisztolyt utánzó öngyújtó. De voltaképpen ugyanez érvényes a már említett keresztre is, ami antik kivégző eszközbôl szent szimbólummá vált.

A hetedik esetben a tartalom és a forma megváltozott, ám a funkció változatlanul fennmaradt. Példa: a római szaturnáliából Karácsony lett, azaz egy pogány ünnep keresztény ünneppé vált. Az ünnep funkciója, amely lényegében az idő strukturálása (napforduló) azonban nem változott.

A nyolcadik változatban a tartalom állandó, viszont megváltozott mind a forma, mind pedig a funkció. Példa: Kodály Zoltán „Székely fonó” című múve, vagy Bartók népzenei alapú szerzeményei. A népdal tartalma (a zenei motívum) megmaradt, de már nem egyszerû emberek énekelgetik munka közben, hanem egy nagyzenekar adja elő több szólamban egy koncert keretében.

A tipológiánk tanulságait levonva azt mondhatjuk, hogy a vírus analógiát akkor használhatjuk, ha egy külsố hatásra bekövetkezố viszonylag gyors változás, pontosabban radikális átalakulás tanúi vagyunk, amely változás elsôsorban a tartalmat érinti, 
azaz az 1-es, 3-as, 6-os, és 7-es esetben. Memetikai öröklődés pedig értelemszerủen a többi esetben, azaz a 2-es, 4-es, 5-ös és 6-os típusnál jelenik meg. Ez utóbbinál a változás a tartalmat nem érinti, azaz feltételezhetô, hogy a tudatosság szerepe ezekben az esetekben elhanyagolhatóbb és inkább egyféle „tág értelemben vett utánzás” történik, semmint tudatos újrakonstruálás.

A fenti tipológia mindazonáltal már születése pillanatától számos problémával terhelt. Elsôként maguk a fogalmak kérdőjelezhetőek meg. Vegyük például a forma fogalmát. A történelem előtti korban állatbőröket használtak fizetőeszközként. Késốbb, amikor is a bôrt felváltotta az elsố fémpénz, a fémlemez továbbra is állatbốrt formált. Nos ebben az esetben mondhatjuk-e azt, hogy a forma változott? A funkció és a tartalom ugyanaz maradt (azaz öröklődött), ám a bőrból fém lett. Ebben az esetben az anyag változott. Ezek szerint itt a forma=anyag, hiszen az nyilvánvaló, hogy ami elsố megközelítésben olyan egyszerúnek tûnt, hogy tehát a forma=alak, jelen esetben nem állja meg a helyét. Ha tehát mégis azt mondjuk, hogy a forma változik, akkor nyelvünk korlátaiba ütközünk.

Ugyancsak problémát jelent, hogy a három kategória: a funkció, a forma és a tartalom kölcsönös összefüggésben állhat. Az egyik átöröklődése maga után vonja a másik öröklődését is, megváltozása a többi módosulását idézheti elő. Amikor tehát öröklődésrốl beszélünk, akkor mit értsünk ezalatt? Mindhárom együttes átadódását? Avagy az egyik áthagyományozódását, és a másik kettőre csupán mint valamiféle járulékos örökségre tekintsünk? Vegyük például az UFO-hitet, amelyrôl azt állítjuk, hogy a hajdani démonhit modern megfelelöje. (Hogy egyenes leszármazottja-e, az még kérdéses.) Ebben az esetben fốként a funkció az, ami a felszínes ismertetójegyeken túl a kettôt összekapcsolja, avagy annyira hasonlóvá teszi, hogy azt mondhatjuk, az előbbi az utóbbi örököse. Más szóval a funkció hordoz egy rejtett szemantikai tartalmat (a démonhit maga, annak fốbb jellemvonásaival), amely viszont nem azonos az explicit szemantikai tartalmakkal (nem szellemlények, hanem űrhajósok, ill. idegen civilizációk, stb.).

Továbbá meg kellene határoznunk, hogy pontosan mit is értünk változáson. Hiszen a változásnak is több típusa lehetséges. Érezzük, hogy más az, amikor mondjuk Anubiszt már nem sakálfejjel, hanem kutyafejjel ábrázolták a Római Birodalom területén, és más az, amikor a félig állat alakú pogány isteneket a teljesen antropomorf szentek váltották fel. Míg az elsố esetben a változás inkább csupán módosulás, a második esetben valódi, gyökeres változás történik. Ennek alapján elemzésünk további finomításokra szorul. A változás fogalma tehát minimum az alábbi típusokba osztható:

1. módosulás: azaz valamiféle kisebb változás, amely azonban a lényeget nem érinti. (Pl. sakálfejú istenségből kutyafejü lesz.)

2. átalakulás: megszűnik az azonosság, a régi helyére valami új kerül, ám ezen új is óriz még valamilyen jegyeket a régiból. (Pl. A régi meghaló és feltámadó istenek helyébe Krisztus lép, aki persze szintén meghal és feltámad.)

3. kicserélődés: a régit felváltja egy teljesen új.

A negyedik a teljes azonosság megórzése, memetikai szempontból ebben az esetben beszélhetünk pontos replikációról.

Az elsô két esetben egy evolúciós analógia - amelyet Kampis György a tudományos paradigmák kapcsán vetett fel - meglehetôsen jól visszaadhatja a változás lényegét 
(Kampis, 2000). Egy szentkép megfestése például, - különösen igaz ez például az ikonfestészetre - szigorú szabályokhoz kötött, amelyeken belül azonban a múvész mégis kap valamiféle szabadságot, amiból adódóan különbözô festốk által festett képek (még az ikonok is), különbözőek lesznek. A teológus, mûvészettörténész és misztikus gondolkodó, Pavel Florenszkij az ikonfestészet kapcsán írja a következôket: „Ha (...) az eredeti mintán keresztül feltárult elốtte a mintán ábrázolt szellemi realitás, s ô, az ikonfestô bár csak másodlagosan -, mégis kellô világossággal látta azt, akkor természetesen az eleven ember eleven realitásának megközelítésekor is megjelenik saját nézőpontja, és nem követi kalligrafikus húséggel az eredeti mintát. Hasonló ez a helyzet ahhoz, mint amikor egy országleírást tartalmazó kéziratot valaki úgy másol le saját kézírásával, hogy a szövegbe saját kifejezéseit is belefoglalja, ettól függetlenül azonban a kézirat továbbra is ugyanazt a leírást tartalmazza, ugyanarról az országról szól. Az ôskép-ikon másolataiban fellelhetố ilyen jellegú különbség egyáltalán nem arra utal, hogy az ikonfestố szubjektíven vagy önkényesen értelmezi az ábrázolandó tartalmat, hanem épp arra, hogy az eleven realitás akkor is önmaga marad, ha - az ikonfestố által is érzékelt szellemi élet eltérô körülményeitól függóen - különféle módokon jelenik meg" (Florenszkij, 1988:37-38). Hasonlóképpen képzelhetjük el a különféle vallási, ideológiai, stb. eszméket is, melyek minden egyes hívő fejében kicsit másként jelennek meg. Az egyedi képek, illetve az egyes emberek fejében lévố hitek az analógia értelmében tekinthetôk egy faj populációjának, amely „lényegileg heterogén, saját változatain keresztül létezô tömeg. Amit paradigmának neveznek, az a valóságos viszonyok között olyan entitás, amelynek létét dinamikus egyensúly biztosítja, változását számtalan forrás táplálja, egyensúlyi helyzete nincsen. Viszonylagos egységét, ha van, nem egy mindenben közös nézetrendszer, azonos nyelv vagy egységesen definiált lexikon, hanem az egyes képviselói fejében lévő változatok közelségi viszonyai és népességszámuk adja” (Kampis, 2000:37). Csakúgy, mint a biológiában, itt is nehéz (tulajdonképpen lehetetlen) meghatározni, mikortól beszélhetünk egy új fajról, amennyiben a változás minden láncszeme előttünk van.

A változás harmadik és negyedik típusában azonban az analógia elveszíti magyarázó erejét. Amikor a régi hiteket, szokásokat valami teljesen új váltja fel, akkor ez az új nem magyarázható a populáció folytonos változásából, hiszen a lényege éppen az, hogy radikálisan más, mint az eredeti. Ezért a hódító kultúrák, eszmék esetében a vírus-analógiát tartom megfelelóbbnek, mert miként a vírus is átalakítja a géneket, megváltoztatja azok információ tartalmát, hogy azután a sejtek neki dolgozzanak, úgy a hódító eszmék is megváltoztatják az emberek fejében lévő mémeket, hogy azután a rítusok, szokások már ez új világkép alátámasztásán, azaz fennmaradásán, túlélésén munkálkodjanak.

A negyedik esetben, amikor gyakorlatilag pontos replikáció történik, szintén nem alkalmazható a heterogén egyedekból álló populáció evolúciós modellje. Egy rítus esetében például pontosan az előírásoknak megfelelően kell eljárni, a legkisebb változás is végzetes lehet, ti. akkor nem múködik a rítus. Hasonlóképpen a vallási fanatikusoknál megfigyelhetô, hogy mennyire ragaszkodnak egy adott szent irat (Biblia, Korán, stb.) betú szerinti igazához, amelyhez sem hozzátenni, sem abból elvenni nem lehet, ami tehát úgy, ahogy van tökéletes és teljes, éppen ezért a maga tökéletes teljességében átörökítendő.

No és mit kezdjünk az olyan típusú jelenségekkel, mint amikor már egyszer megjelent eszme eltûnik a történelemben, majd esetleg évszázadok vagy akár évezredek múltán újra felbukkan más kulturális környezetben, s ennek révén egészen más 
„szemantikai burokban”, vagyis más formában. Jó példája ennek az atomizmus, amelyrôl tudjuk, hogy ugyan Demokritosz és Leukipposz atomizmusa egészen más jellegú, mint a modern atom-elmélet, ez utóbbit mégis hajlamosak vagyunk az előbbibốl származtatni. Annál is inkább, mert errôl az elméletrôl mindvégig tudtak az antik világtól az újkorig. De mi a helyzet azoknak az igen ôsi elképzeléseknek az esetében, amelyek meglehetôs makacs szívóssággal újból és újból felbukkannak a legkülönfélébb korokban és kultúrákban. (Ezek egy külön tanulmányt megérnének.) Ilyen például az antropomorf kozmosz eszméje. Ennek legarchaikusabb verziója szerint a látható külvilág minden ízében ember alakú, sőt a mítoszban ez egy kozmikus embert alkot. Így az ógermán Eddában Ymir, vagy a Védákban, majd az Upanisádokban Purusa, azaz Ós-Ember, akinek testrészeiból a világ keletkezik. (A példákat tovább sorolhatnánk.) Ezekben az elképzelésekben a domborzat a testi domborzat, a növényzet a szốrzet, a folyóvizek az erek, az égbolt a koponyatető, stb. Vajon ez az archaikus elképzelés finomult-e ki a kereszténységben és vált központi dogmává: „az ember, mint a világmindenség középpontja" eszmévé. Továbbá vajon ez utóbbi-e az ihletője vagy a szülőatyja a modern kozmológiában megjelenő ún. „erôs” antropikus elvnek. Habár a három eszme hihetetlen különbségeket mutat, lényegük, szemantikai magvuk egy metaforára redukálható, miszerint a világ (vagy kozmosz) = ember(alakú). No és ennek lennének különböző evolúciós fázisai a primitív-archaikus naturális antropomorfizmus (amelyrôl a pszichoanalízisből tudjuk, hogy a tudattalan fantáziában mindmáig eleven), az antropocentrikus kozmosz, amelynek elválaszthatatlan része volt „az ember egy kis világegyetem (mikrokozmosz)” elképzelés is, és a jelenlegi kozmológiai hipotézisként divatos „emberszabású” világegyetem?

Vajon beszélhetünk-e itt valamiféle kulturális öröklődésrôl, az elképzelés történelmileg is nyomon követhető evolúciójáról, avagy az emberrel születő, az emberben benne rejlő ôsi elképzelések ezek, egy meglévő készlet darabjai, nevezzük ôket akár avitt módon Jung után archetípusnak, vagy korszerúbben Denett után „kulturális univerzáliák"-nak (Denett, 1998:384).

Sajnos egy ilyen átfogó szemléletû dolgozat nem ad teret arra, hogy a szerzố elmerülhessen a részletekben, hiszen a benne felmerülő konkrétumok csupán példák, és leírásuk feltételezi, hogy azok jobbára talán közismert dolgok, sốt helyenként közhelyek. A lényegi mondanivaló itt tehát nem a bon vs. buddhizmus, vagy a marxizmus vagy éppen a Nyugat-Római Birodalom kulturális hagyatéka, ezek pusztán kiragadott, sốt, ha úgy tetszik: önkényesen, találomra kiragadott példák. Ám ez a dolgozat jellegéhez tartozik, mivel általános törvényszerûségekrôl van szó. Természetesen lehet, hogy példáim helyenként nem állják meg a helyüket - fôként az esetleges tárgyi tévedések végett -, de ettől még a probléma maga, azaz az alapvető törvényszerúségek, az öröklődés, vagy az átadás törvényszerûségeinek problémái ugyanazok maradnak.

\section{Zárszó: lehetséges tanulságok}

Amíg a kultúrát távolról szemléltük, analógiáink múködóképesnek bizonyultak. Az alaposabb analízis azonban számos problémát vetett fel, amelyek alapján felmerül a kérdés: mi szükség van egyáltalán az ilyen analógiákra? Használatukkal vajon nem reked-e meg elemzésünk a „szalonfilozófia” szintjén? Az a kérdés tehát, hogy az analógiák valóban adnak-e egy új dimenziót, egy mélyebb megértést. Avagy a terjedési 
elméletek alkalmazása a kultúra bizonyos jelenségeire pusztán egy egyszerű „fordítás" vagy leképezés, vagyis hogy voltaképpen nem tettünk mást, mint hogy egy adott jelenséget most más szavakkal írtunk le. A (biológiai) analógia persze mindig csak részleges lehet. Amiért viszont mégsem elvetendő, az az újszerű megközelítés, amely a kulturális jelenségeket, mint eleven organizmusokat, önszervezôdố rendszereket szemléli. Ez pedig számos olyan szempontot villanthat fel, ami más megközelítésben elsikkadna. Ugyanakkor öröklődésról, evolúcióról nem beszélhetünk releváns, pontos, hiteles módon, ha elsikkadunk az analitikus szempontok felett. Ahhoz, hogy a memetika valóban komoly tudománnyá váljon, egyrészt tehát arra volna szükség, hogy a makrofolyamatok mellett végre a mikrojelenségekre is figyeljen, másrészt egy igazi interdiszciplináris párbeszéd szükséges az etnográfia, az antropológia és nem utolsósorban a régészet bevonásával, hiszen ezek azok a tudományok, amelyek explicit módon foglalkoznak a különböző kulturális jelenségek, tárgyak evolúciójával, áthagyományozódásával, öröklődésével.

A fent tárgyalt kulturális evolúciós folyamatok, fốként a „kis tradíció” vs. a „nagy tradíció" kettôssége, némi tanulsággal szolgálhat számunkra az információs társadalom szerepét, vagy még inkább: annak mibenlétét illetően is. Az információs társadalom megjelenését egyesek, mint „mémrobbanást”, azaz a mémek robbanásszerú replikációját és szaporodását hajlamosak interpretálni. Most már bizony a technológiai fejlődés révén jóval több mém versenyezhet a figyelmünkért, vagyis a fennmaradásért és az elterjedésért - akárcsak az áruk a piacon. Nos, az információs társadalom ideája úgy túnik, szétbogozhatatlanul összefonódott a (neo)liberalizmus, a multikulturalizmus, a szabadpiac, a globalizáció eszméivel, s ez az eszme(iség) jelenleg már-már klasszikus utópiává látszik kinôni magát: Szabadság, individualizmus, demokrácia, nyitott társadalom, áruk és eszmék szabad áramlása. A technikai fejlôdésbe, illetve a haladásba vetett hit egyébként már a hatvanas-hetvenes évek új baloldali mozgalmaiban is összefonódott az igazságos társadalom eszméjével, s ez az optimizmus (?) a baloldali eszmék perifériára szorulása után is fennmaradni látszik, mint a liberális/neoliberális gondolkodás egyik fő ideológiai támpillére. Sokan már akkor úgy vélték, hogy az újfajta igazságos társadalom a technikai fejlődés eredményeképpen fog beköszönteni. Marshall McLuhan (és mások) szerint az elektronikus hírközlő eszközök bolygónkat „globális faluvá” fogják változtatni, a televízió, illetve a számítógépeknek köszönhetően az információ mindenki számára egyaránt hozzáférhető lesz, s ezzel az egyenlőség és igazságosság új alapja teremtôdik meg. A (neo)liberalizmus, illetve a multikulturalizmus ígéretének lényege pedig a nyugati életforma, s vele a demokrácia világméretű elterjedése, a nyitott társadalom, mint követendő modell megerôsödése, amely idővel a tradicionális életformák, hiedelmek, stb. eltúnését eredményezi. Az individualitás hangsúlyozásával, a „másság” elfogadásával megszűnnek az előítéletek, a sztereotípiák az emberi gondolkodásban, és így tovább és tovább.

Az Internet kiépülésével, a mobil telefonok elszaporodásával valóban megsokszorozódtak a mémek (vagy vírusok) túlélési és terjedési lehetôségei. De vajon tényleg változtatott-e, illetőleg változtathat-e az információ-dúsulás a kulturális berögzültségeken, vagy azokat még inkább alkalmazkodóbbá teszi? Nos, egyelőre úgy tûnik, hogy bizonyos hiedelmek és hagyományok az új technológiát eszköznek tekintik és nem akadálynak, s így ragyogóan elboldogulnak. Szó sincs arról például, hogy az információ-dúsulás eltörölné a különféle előítéleteket, a babonás gondolkodást, vagy a 
rasszizmust, stb. Ezek kiválóan alkalmazkodtak, s újra meg újra (sốt, gyakran megerôsödve) bukkannak fel hol burkoltan, hol egészen nyíltan. Elég, ha csak az Interneten elérhetố neo- és régivágású náci weboldalakra, vagy éppen okkultista könyvek, cikkek, egyéb információk garmadájára gondolunk. Sôt, az Internetre felkerülő anyagok között éppen ezek állnak a (pornó utáni) második helyen. Amíg például a „Mein Kampf”-hoz, vagy a „Cion bölcseinek jegyzôkönyve”-hez egyáltalán nem lehetett hozzájutni a szocializmus információszegény, zárt társadalmában, de ugyanígy asztrológiai, s egyéb okkultista iratokhoz vagy keresztény szekták kiadványaihoz sem (szinte már az is kiváltság volt, hogy ha valaki rendelkezett egy-egy nehezen megszerezhetố könyv fénymásolt példányával), ma egy sor, ezekre a témákra specializálódott, könyvesboltot találunk még Budapesten is. Amíg a tudományos cikkekben, könyvekben (egy-két szakma kivételével) a háló mind a mai napig szégyenletesen szegényes, addig a különféle okkult és rasszista témák áttekințhetetlen bôségével találja szembe magát a szörfölő. Jellemző, hogy az Internet (virtuális) teret enged a legavíttabb eszméknek is, sôt: ezek teljesen modern formában jelennek meg újra, felvéve az internetes-globalista kultúra minden külsôségét. Jó példa erre, hogy az egyik magyar irredenta csoportosulás, amely fốként a világhálón nyomul, rendszeresen beszámol az „oláh-magyar” hackerháborúról. (Ti. román és magyar nacionalista fiatalok rendszeresen feltörik egymás kódjait, gyalázkodó üzeneteket küldve a másik félnek.) Vagy vegyünk egy egészen aktuális példát: a magát nemzeti-keresztény konzervatívnak nevező (többségükben szintén fiatal) aktivisták SMS-ekkel szervezik megmozdulásaikat, sốt ôk maguk „SMS-forradalom”-nak nevezték a FIDESZ kampányzáró nagygyúlését. Vagy hogy egy egészen ismert dolgot említsek fel újból: az iszlám fundamentalisták is az Interneten szervezték-szervezik akcióikat. Egyszóval azok az eszmék, hagyományok, gondolkodásformák, amelyeket a multikulturális'-globalista világ apostolai úgy szeretnek halálra ítélni, éppen az információ szabad áramlása révén születnek újjá.

Vajon nem mondhatjuk-e azt, hogy a globalizáció és az ahhoz társított multikulturalizmus/információs társadalom eszméje voltaképpen egy vérbeli, hamisítatlan „nagy tradíció” (politikusabban fogalmazva: a jelenlegi uralkodó elit világnézete), amely mellett (vagy amelyen belül) számos „kis tradíció” éli tovább megszokott életét? Mert mi tesz egy mémet életképesebbé?

- Szeretném ezúton megköszönni Farkas Attila Márton segítségét, valamint Kampis György, Kolin Péter, Sárkány Mihály, Somlai Péter és Wessely Anna segítő kritikáit.

\section{JEGYZETEK}

${ }^{1}$ A tudatos/tudattalan fogalompárt jobb híján használom jelen tanulmányban, bízva abban, hogy az írás egésze, majd érzékelteti, miként is értendôk.

2 Derk Bodde: Harmony and Conflict in Chinese Philosophy - idézi Redfield 1956:89.

${ }^{3}$ A buddhizmus tibeti történetérốl lásd pl.: Eliade, 1996:228-235; Samuel,1993; Snellgrove, 1987; Tucci, 1972. A bon sámánisztikus hagyományáról, illetve arról, hogy az hogyan kevere- 
dett a buddhizmus tanaival. (Eliade, Tucci, 2001:387-399; Hoffmann, 1961). A lámaizmus egyes népi aspektusairól: Nebelsky-Wojkovitz, 1956.

4 Az intézményesülés fogalma némi félreértésre adhat okot. Ezt elkerülendő tisztáznunk kell a következőket: Amikor egy új eszme megjelenik, akkor kezdetben (többé-kevésbé) mindenki, akit megérint, szellemi útkeresésként viszonyul hozzá. Amint azonban az eszme (legyen az egy vallás, egy politikai ideológia, vagy éppen egy tudományág, stb.) intézményesül, akkor már csak az elit számára jelent útkeresést, azok számára azonban, akik nem tagjai az elitnek, az eszme rutin eljárásokká, sablonná, egyszerú rítusok és klisék halmazává változik.

${ }^{5}$ Ez némileg rárímel a kulturális antropológiában jól ismert, Marvin Harris nevéhez füzôdő, ún. „emikus” és „etikus” megközelítésére a kultúrának. Az előbbi azon a szemléletmódon alapul, ahogyan az adott kultúrát saját képviselói látják, az „etikus” megközelítés viszont kívülrôl történő, objektív-tudományos attitúdöt jelent. (Harris, 1979.) Természetesen mindkét megközelítésnek megvannak a maga elốnyei és hátrányai. Amikor azonban valaki a kulturális evolúció jelenségét vizsgálja, ami némely esetben akár több koron és kultúrán is átívelô folyamat, akkor sokkal célszerúbb az „etikus” megközelítés alkalmazása, hiszen ennek révén tudjuk összekapcsolni a különböző korok és népek hiedelmeiben, rítusaiban a hasonló elemeket, és megállapítani, hogy az adott kulturális elemek hogyan változnak az idők során.

" A mára már bevett „tudni hogyan” és „tudni mit” Gilbert Ryle terminusai, amelyekkel az értelmes cselekvéseket különböztette meg a szokás vezérelt cselekvésektől. „Nem mondjuk a gyerekról: tudja, hogyan játsszon, ha semmi mást nem tud, csak pontosan felmondani a szabályokat. Képesnek kell lennie arra is, hogy megtegye a szükséges lépéseket. De azt mondjuk, tudja, hogyan játsszon, ha rendes körülmények között a megengedett lépéseket teszi, elkerüli a tiltottakat és óvást emel, ha ellenfele tesz tiltott lépéseket - bár nem tudja idézni a szabályokat. (...) A pusztán szokásból végzett gyakorlat lényege az, hogy az egyik ténykedés másolata az előzóeknek. Az értelmes gyakorlat lényege pedig az, hogy az egyes ténykedéseket módosítják a megelőzók. A cselekvő személy ugyanis még tanul.” (Ryle, 1999:53-54)

7 Természetesen tisztában vagyok avval, hogy a „tartalom”, „forma” és „funkció” szavak annyira általánosak, hogy definiálásra szorulnak. Erre késốbb majd visszatérek, egyelôre hétköznapi értelmükben használom őket.

8 A mémek - (Dawkins, 1986:250) - „öntudatlan, vak replikátorok. Az a tény, hogy replikálódnak, bizonyos további feltételekkel együtt azt jelenti, hogy akarva, nem akarva, olyan tulajdonságok kifejlődése irányában haladnak, melyek e könyv sajátos szóhasználatával önzônek nevezhetôk.”

9 Klasszikus kultúr-gén elméletet fogalmazott meg pl.: Wilson - Lumsden (1981), Luigi Cavalli-Sfroza és Marcus Feldman (1981).

${ }^{10}$ Ugyanakkor néhány oldallal késốbb (Dennett, 1998:373) látjuk, hogy Denett mégsem határolódik el ettől az elképzeléstől, sőt, nagy jelentőséget tulajdonít annak, hogy agyunkat kulturálissá a mémek alakítják: „Az emberi agyak kultúra általi, a mémek formájában történő inváziója létrehozta az emberi elmét" (Dennett, 1998:397)

" „Otto Bauer már 1914 előtt felvetette, hogy szükséges sokféle szocializmus-eszmével dolgozni, melyek az eltérôn nemzeti és kulturális környezetet tükrözik. (...) Bauernak az a megállapítása, hogy «az egyes nemzetek kulturális karaktere rányomja bélyegét szocializmusukra is« egyetemes jelentőségú volt.” (Wright, 1999:37); Az egyiptomi szocializmusról lásd Gazdik, 1986:99-103; az arab szocializmusról általában: Abdel 1972.

${ }^{12}$ A vallás, az egyházak illetve az azokkal való kiegyezés kérdése más, mivel az a marxizmus, azaz az uralkodó félig-meddig rivális vallásként szolgáló ideológia alapdogmáit sértette. 
${ }^{13}$ A II. Sándor cár elleni merénylet után az emigrációban Vera Zaszulics Marxhoz fordult tanácsért. „Azt kérdezte, vajon a forradalmárok teendôje ezek után az, hogy elôsegítsék a kapitalizmus fejlődését, hiszen Marx szerint a szocialista forradalom csak a fejlett tôkés országokban győzhet.” Marx azt válaszolta, hogy „amennyiben az oroszországi forradalom nyomán Nyugaton is győz a forradalom, akkor az orosz forradalmárok a meglévö szocialista alapokon (vagyis aะ obscsinán) felépíthetik a szocializmust. Az obscsinát, mint aะ ösztönös szocializmus alapját már Herzen meghirdette.” (Krausz, 1997:412)

${ }^{14}$ Az obscsina forradalmat elemezve Buharajev hasonló következtetésre jut (bár a biológiai analógiát történelmi elemzésében nem használja), amikor a következóket írja: „Az orosz történelem erősebbnek bizonyult a bolsevikok mesterkedéseinél. A „proletár internacionalizmus” színeiben egy sajátos formában feltámadt tulajdonképpen az egész orosz nagyhatalmiság. (...) Ha a forradalom utáni fejlôdés valóban egy „plebejus forradalom” eredménye volt ugyanis, mi magyarázza akkor, hogy nem egy plebejusodás, hanem - fentról lefelé haladva - egy határozott „elparasztiasodás” ment végbe az egész társadalomban?” (Buharajev, 1998:51).

${ }^{15}$ Hangsúlyozni szeretném, a szocializmus csak példa, nem állítom szembe e tekintetben a kapitalizmussal, hiszen nyilvánvaló, hogy a kapitalizmus is alkalmazkodik a lokális kultúrához, az sem egységes. Mindazonáltal a kapitalizmus lokális megjelenései is csupán példák lennének - de hát nem írhatok le minden példát a kis- és nagy tradíció kettôsségére. A dolgozat bírálói közül többen szememre vetették, hogy elsikkadtam a marxizmus modernizációs hatása felett. Az iparosodás, a gyárépítések, stb. tényét egyáltalán nem vonom kétségbe, ám a folyamat lényegét egészen másként látom. A modernizáció a kapitalista fejlődéssel is létrejött volna, legalábbis azokban a térségekben, amelyek közelebb álltak a Nyugathoz, a távolabbi térségekben azonban a szocializmus semmilyen tekintetben nem modernizált. A modernizáció csupán eszköz volt a társadalmi „mélystruktúrák” tartósítására. Nem véletlen, hogy a volt szocialista országok most érkeztek el a kapitalista fejlődéshez, nem véletlen, hogy a legdurvább (XIX. századi) szabadversenyes kapitalizmust tapasztaljuk most saját bőrünkön.

${ }^{16}$ Lengyelország és Írország kivételt képez, mivel ezekben az országokban valóban speciális történelmi okok játszottak szerepet. Angliát azonban „kulturálisan katolikusnak” kell tekinteni, mivel az anglikán egyházat a legjobb tudomásom szerint nem sok minden különbözteti meg a katolikus egyháztól. Sem rítus, sem dogma, sem külsőség, sem belsőség, csupán Rómától való függetlensége, amelynek egykori aktuálpolitikai okait ismerjük. Skócia pedig keményen presbiteriánus, a felföldiek (az egykori jakobiták) maradtak viszont katolikusok. E kérdésben a valódi ellenpéldákat az írek és a lengyelek jelentik. Azonban e két esetben is elsősorban a sajátságos geopolitikai helyzet, azaz a kényszerítő szükség volt az, amely a katolicizmust a nemzeti-kulturális identitás legfóbb letéteményeseként tartotta meg (sốt, meg is erősítette). Ez a speciális, a kivétel, amely megbontja a nagyobb egységet. Mert létezik nagyobb egység, mégiscsak egyeznek a földrajzi határok, amelyeket így talán valamiféle kulturális határokként (is) lehetne kezelni. Lehet, hogy nincs közvetlen, kimutatható oksági kapcsolat, de valamiféle „rejtett összefüggésnek” kell lennie.

${ }^{17}$ Lehet, hogy az olvasónak világosak az összefüggések, mert olvastak politikai filozófiát vagy ismerik a liberalizmus alapelveit, ám ez a tudatosság az említett kulturális holdudvart alkotó emberek zömére korántsem jellemzô. Mind a buddhizmus, mind az SZDSZ esetében jellegzetes „hívő” hozzáállásról van szó. Saját tapasztalatból tudom, hogy ezek az emberek, mint igazi hívôk, ezeket az eszme-társulásokat automatikusan elfogadják, anélkül, hogy bármikor is megkísérelnék feloldani a látszólagos ellentmondást, illetve anélkül, hogy ismernék a mélyebb szemantikát feltáró politikai, filozófiai alapokat. A nyugati, illetve hazai buddhizmus- 
ról lásd: Farkas 1998. A hívő ember elméje nem gondolkodik a látványos ellentmondásokon, hanem automatikusan, mint koherens eszmerendszert fogad el mindent, ami a politikailag (valójában azt hiszem: kulturálisan) szimpatikus párttól jön. A pártszimpátia - legalábbis nálunk - inkább kulturális elkötelezettség, amolyan „törzsi tudat”-féle. Ezért hozom a példát, s ez alapján próbálom a hajléktalanok vs. vadkapitalizmus ellentmondását feloldani. Nyilván e párt - ill. annak holdudvara - esetében speciális magyar példáról van szó, az SZDSZ-t nem lehet más nyugati pártokhoz, (mint pl. a német szabaddemokraták) hasonlítani. Mint minden esetben, itt is egy sajátos helyi fejlődésről van szó, ebben az említett példában tradíciók vannak benne: Solt Ottília és a SZETA együtt a mindenkori Nyugat- ill. Amerika barátsággal, ill. szimpátiával. Vagyis szó sincs - legalábbis a politizálásnak ezen a szintjén - racionalitásról, sokkal inkább hagyományokról és érzelmi kötelékekról.

\section{IRODALOM}

Abdel Moghy Said, (1972): Arab Socialism, London.

Bausinger, Hermann, (1995): Népi kultúra a technika korszakában. Budapest, Osiris - Századvég.

Blackmore, Susan, (2001): A mém-gépezet. Magyar Könyvklub.

Buharajev, Vlagyimir, (1998): Az „obscsina-forradalom” pirruszi győzelme. In: Krausz Tamás (szerk.): 1917 és ami utána következett. (37-52.) Rusztikai könyvek III. Magyar Rusztikai Intézet.

Cavalli-Sfroza, L. L. \& Feldman, M. W., (1981): Cultural Transmission and Evolution: A Quantitative Approach. Princeton, NJ, Princeton University Press.

Daniels, R. V., (1990): The Stalin Revolution: Foundation of Totalitarian Era. Toronto.

Dennett, Daniel C., (1998): Darwin veszélyes ideája. Budapest, Typotex.

Dawkins, Richard, (1986): Az önző gén. Budapest, Gondolat.

(1989): A hódító gén. Budapest, Gondolat.

Deutcher, I., (1990): Sztálin. Politikai életrajz. Budapest.

Dobrovits Aladár, (1979): Sakál a bárkában. In: Irodalom és vallás az ókori Egyiptomban II. (211-217). Budapest, Akadémiai Kiadó.

Durkheim, Emil, (1915): The Elementary Forms of the Religious Life. London, Allen and Unwin.

Dünninger, Josef, (1937): Volkswelt und Geschichtliche Welt. Berlin - Leipzig - Essen.

East, Rupert, (1930): Akiga's Story. Fordította és kommentárokkal látta el. London, Oxford University Press.

Farkas Attila Márton, (1998): Buddhizmus Magyarországon avagy az alternatív vallásosság egy típusának anatómiája. MTA Politikai Tudományok Intézete.

Fedotov, G. P., (1992): Pravda pobezsgyonnih. In: Fedotov: Szugyba i grehi Rosszii. 2., Szentpétervár.

Florenszkij, Pavel, (1988): Az ikonosztáz. Corvina Kiadó.

Gazdik Gyula, (1986): A nasszeri szocializmus-koncepció fốbb vonásai. In: Társadalomelmélet. Szocialista fejlődés. (99-103.) ELTE BTK Tudományos Szocializmus Tanszék. 
Gill, J. Graeme, (1990): The Origines of the Stalinist Political System. Cambridge.

Harris, Marvin, (1979): Cultural Materialism. Random House, Inc.

Hoffmann, H., (1961): The Religions of Tibet. London.

Jordán Gyula, (1999): Kína története. Aula Kiadó.

Kampis György, (2000): A tudás folytonossága a paradigmák rendszerében. Világosság 2000/11-12::32-42

Krausz Tamás, (1996): Sztálin. Budapest.

Krausz Tamás \& Font Mária \& Niederhauser Emil \& Szvák Gyula, (1997): Oroszország története. Maecenas Kiadó.

Lumsden, G. J. \& Wilson, E. O., (1981): Genes, Mind and Culture. Cambridge, MA, Harvard University Press.

Eliade, Mircea, (1996): Vallási hiedelmek és eszmék története III. Budapest, Osiris Kiadó. (2001): A samanizmus. Budapest, Osiris Kiadó.

Nebelsky-Wojkovitz, R., (1956): Oracles and Demons of Tibet. Den Haag.

Pléh Csaba, (2000): A gondolatok terjedési mechanizmusai: mémek vagy fertôzések. Replika 40. (2000. június): 165-185.

Redfield, Robert, (1956): Peasant Society and Culture. An Anthropological Approach to Civilization. The University of Chicago Press.

Ryle, Gilbert, (1999): A szellem fogalma. Budapest, Osiris Kiadó.

Samuel, G., (1993): Civilized Shamans: Buddhism in Tibetan Societies. Washington - London.

Snellgrove, David, (1987): Indo-Tibetan Buddhism: Indian Buddhists and their Tibetan Successors. Boston.

Sperber, Dan, (2001): A kultúra magyarázata. Budapest, Osiris Kiadó.

Tucci, G., (1972): The Religions of Tibet. Berkley, California.

Wittgenstein, Ludwig, (1989): Logikai - filozófiai értekezés. Budapest, Akadémiai Kiadó.

Wright, Tony, (1999): Régi és új szocializmusok. Budapest, Napvilág Kiadó. 